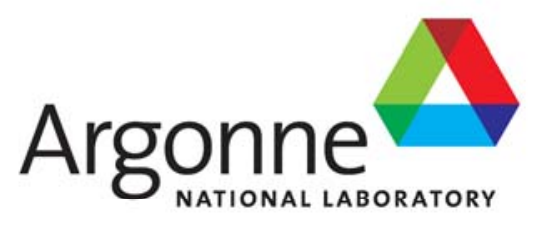

\title{
Management of Water Extracted from Carbon Sequestration Projects
}

Environmental Science Division 
This work was funded by the Department of Energy National Energy Technology

Laboratory (NETL) Carbon Sequestration Program.

About Argonne National Laboratory

Argonne is a U.S. Department of Energy laboratory managed by UChicago Argonne, LLC under contract DE-AC02-06CH11357. The Laboratory's main facility is outside Chicago, at 9700 South Cass Avenue, Argonne, Illinois 60439. For information about Argonne and its pioneering science and technology programs, see www.anl.gov.

\section{Disclaimer}

This report was prepared as an account of work sponsored by an agency of the United States Government. Neither the United States Government nor any agency thereof, nor UChicago Argonne, LLC, nor any of their employees or officers, makes any warranty, express or implied, or assumes any legal liability or responsibility for the accuracy, completeness, or usefulness of any information, apparatus, product, or process disclosed, or represents that its use would not infringe privately owned rights. Reference herein to any specific commercial product, process, or service by trade name, trademark, manufacturer, or otherwise, does not necessarily constitute or imply its endorsement, recommendation, or favoring by the United States Government or any agency thereof. The views and opinions of document authors expressed herein do not necessarily state or reflect those of the United States Government or any agency thereof, Argonne National Laboratory, or UChicago Argonne, LLC. 


\section{Management of Water Extracted from Carbon Sequestration Projects}

prepared by

C.B. Harto and J.A. Veil

Environmental Science Division, Argonne National Laboratory

January 2011 



\section{CONTENTS}

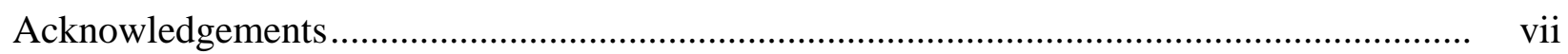

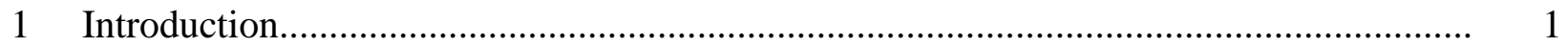

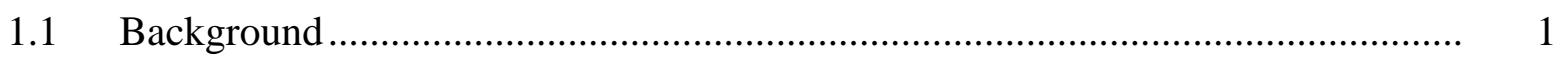

1.2 Purpose and Structure of the Report ...................................................................... 1

2 Evaluation of Formations and Water Quality Data .......................................................... 3

2.1 Evaluation of Formations Likely To Be Used for Carbon Sequestration............... 3

2.2 Water Quality Data for Geological Formations Likely To Be Used for Sequestration ............................................................................................... 4

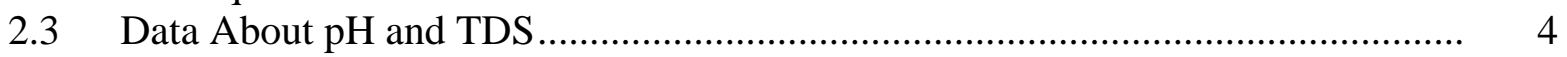

2.4 Data About Other Chemical Constituents................................................................. 9

$3 \quad$ Extracted Water Quantity Estimates.................................................................................... 13

$4 \quad$ Water Management Technologies and Practices ................................................................... 15

4.1 Water Management Hierarchy for Evaluation of Management

Technologies and Options..................................................................................... 16

4.1.1 Tier 1 - Minimization ......................................................................... 16

4.1.2 Tier 2 - Recycle and Reuse ………………………………………... 16

4.1.3 Tier 3 - Disposal ................................................................................ 17

4.2 Use of Extracted Water for Secondary Purposes ..................................................... 17

4.2.1 Geothermal Energy ………………………………............................... 19

4.2.2 Extraction of Mineral Commodities ........................................................... 22

$5 \quad$ Cost of Extracted Water Management................................................................................. 25

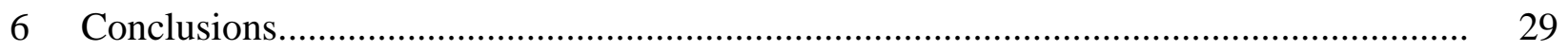

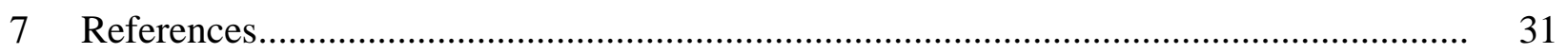

APPENDIX A: Table of Deep Saline Formations That Have

Geochemical Data Available 


\section{FIGURES}

$1 \quad$ Histogram of Median Formation pH................................................................... 5

$2 \quad$ Histogram of Median Formation TDS ....................................................................... 6

$3 \quad$ BSCSP and PCOR Partnerships Formation TDS Box Plot ........................................... 7

$4 \quad$ MRCSP and MGSC Partnerships Formation TDS Box Plot ......................................... 7

$5 \quad$ SECARB Partnership Formation TDS Box Plot ................................................. 8

$6 \quad$ SWP Partnership Formation TDS Box Plot.................................................................... 8

$7 \quad$ WESTCARB Partnership Formation TDS Box Plot ..................................................... 9

$8 \quad$ Brine Composition — Major Constituents ................................................................ 10

$9 \quad$ Brine Composition — Minor Constituents ................................................................ 10

$10 \quad$ Illustration of $\mathrm{CO}_{2}$ Density Variation with Depth....................................................... 13

\section{TABLES}

$1 \quad$ Estimated Saline Formation Storage Resources ……………………………................ 3

2 Brine Constituent Classification Scheme........................................................................ 11

$3 \quad$ Comparison with National Primary Drinking Water Standards .................................... 12

$4 \quad$ Comparison with National Secondary Drinking Water Standards ................................ 12

$5 \quad$ Water Minimization Technologies for Extracted Water.................................................. 16

$6 \quad$ Water Reuse and Recycle Management Options for Extracted Water .......................... 18

$7 \quad$ Water Disposal Technologies for Extracted Water …………….................................. 20

$8 \quad$ Water Technologies for Removing Salt Content ............................................................ 21

$9 \quad$ Water Technologies for Removing Oil and Grease Content ......................................... 22

10 Costs for Produced Water Disposal .................................................................... 26 


\section{TABLES (Cont.)}

11 Costs for Treatment to Remove TDS.......................................................................... 27

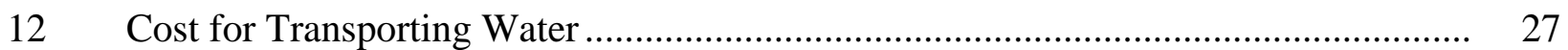




\section{ACKNOWLEDGEMENTS}

The authors would like to thank the U.S. Department of Energy's (DOE's) National Energy Technology Laboratory (NETL) Carbon Sequestration Program for providing funding to support the project. We offer a special acknowledgement to the NETL project manager, Andrea McNemar. The work was supported through Field Work Proposal 49607. 


\section{INTRODUCTION}

\subsection{Background}

Throughout the past decade, frequent discussions and debates have centered on the geological sequestration of carbon dioxide $\left(\mathrm{CO}_{2}\right)$. For sequestration to have a reasonably positive impact on atmospheric carbon levels, the anticipated volume of $\mathrm{CO}_{2}$ that would need to be injected is very large (many millions of tons per year). Many stakeholders have expressed concern about elevated formation pressure following the extended injection of $\mathrm{CO}_{2}$. The injected $\mathrm{CO}_{2}$ plume could potentially extend for many kilometers from the injection well. If not properly managed and monitored, the increased formation pressure could stimulate new fractures or enlarge existing natural cracks or faults, so the $\mathrm{CO}_{2}$ or the brine pushed ahead of the plume could migrate vertically.

One possible tool for management of formation pressure would be to extract water already residing in the formation where $\mathrm{CO}_{2}$ is being stored. The concept is that by removing water from the receiving formations (referred to as "extracted water" to distinguish it from "oil and gas produced water"), the pressure gradients caused by injection could be reduced, and additional pore space could be freed up to sequester $\mathrm{CO}_{2}$. Such water extraction would occur away from the $\mathrm{CO}_{2}$ plume to avoid extracting a portion of the sequestered $\mathrm{CO}_{2}$ along with the formation water. While water extraction would not be a mandatory component of large-scale carbon storage programs, it could provide many benefits, such as reduction of pressure, increased space for $\mathrm{CO}_{2}$ storage, and potentially, "plume steering."

\subsection{Purpose and Structure of the Report}

Argonne National Laboratory is developing information for the U.S. Department of Energy's (DOE’s) National Energy Technology Laboratory (NETL) to evaluate management of extracted water. If water is extracted from geological formations designated to receive injected $\mathrm{CO}_{2}$ for sequestration, the project operator will need to identify methods for managing very large volumes of water most of which will contain large quantities of salt and other dissolved minerals. Produced water from oil and gas production also typically contains large quantities of dissolved solids. Therefore, many of the same practices that are established and used for managing produced water also may be applicable for extracted water.

This report describes the probable composition of the extracted water that is removed from the formations, options for managing the extracted water, the pros and cons of those options, and some opportunities for beneficial use of the water. Following the introductory material in Chapter 1, the report is divided into chapters covering the topics listed below: 
- Chapter 2 examines the formations that are likely candidates for $\mathrm{CO}_{2}$ sequestration and provides a general evaluation of the geochemical characteristics of the formations.

- Chapter 3 makes some preliminary estimates of the volume of water that could be extracted.

- Chapter 4 provides a qualitative review of many potential technologies and practices for managing extracted water. For each technology or management practice, pros and cons are provided.

- Chapter 5 explores the potential costs of water management.

- Chapter 6 presents the conclusions. 


\section{EVALUATION OF FORMATIONS AND WATER QUALITY DATA}

\subsection{Evaluation of Formations Likely To Be Used for Carbon Sequestration}

Although the main focus of this study is evaluating different options for managing the water that would be extracted from formations receiving $\mathrm{CO}_{2}$, it was first necessary to gain an understanding of the location, quality, and quantity of the water that would be managed. According to NETL, deep saline formations have the greatest potential storage capacity for sequestration; therefore, they were the focus of this study (2010).

The first activity involved compiling a list of deep saline formations with potential for carbon sequestration. Deep saline formations are characterized by high porosity and are typically saturated with brine. Formations suitable for sequestration have an overlying, impermeable, low porosity capping layer that confines the sequestered gas and prevents migration. Sequestration is also expected to be more effective at depths below 2,500 feet due to the high density of $\mathrm{CO}_{2}$ at the typical pressures and temperatures encountered at those depths (Bentham and Kirby 2005). In general, much less is known about these formations than hydrocarbon-containing formations. Despite the more limited characterization, it has been estimated that saline formations may be capable of sequestering between 1.7 and 20 trillion metric tons of $\mathrm{CO}_{2}$ (NETL 2010). This is at least an order of magnitude greater than the estimated sequestration potential of oil and gas reservoirs and unmineable coal seams combined. Table 1 contains a summary of the estimated storage resource of saline formations within each of the DOE regional carbon sequestration partnerships.

TABLE 1 Estimated Saline Formation Storage Resources; billion metric tons $\mathrm{CO}_{2}$ (Gt)

\begin{tabular}{lrr}
\hline \multicolumn{1}{c}{ Partnership } & Low Estimate & High Estimate \\
\hline & & \\
Big Sky Carbon Sequestration Partnership (BSCSP) & 221 & 3,041 \\
Midwest Geological Sequestration Consortium (MGSC) & 12 & 160 \\
Midwest Regional Carbon Sequestration Partnership (MRCSP) & 46 & 183 \\
Plains CO 2 Reduction Partnership (PCOR) & 165 & 165 \\
Southeast Regional Carbon Sequestration Partnership (SECARB) & 908 & 12,527 \\
Southwest Regional Partnership on Carbon Sequestration (SWP) & 219 & 3,013 \\
West Coast Regional Carbon Sequestration Partnership (WESTCARB) & 82 & 1,124 \\
& & \\
Total & 1,653 & 20,213 \\
\hline
\end{tabular}

Source: Table adapted from NETL (2010).

A working list of deep saline formations suitable for carbon storage was pieced together from data available from the seven DOE regional carbon sequestration partnerships. Data sources included both published reports and unpublished data obtained by directly contacting researchers at the partnerships. A total of 99 basins or formations were identified through this search. The list is not considered exhaustive or complete, but it provides a useful starting point 
for the characterization of the saline brines that may be encountered. It should be noted that the list contains some geographical overlap as different sources reported data at either the basin or formation level. The list of formation names can be found in Appendix A along with storage capacity estimates and formation depths where data were available.

\subsection{Water Quality Data for Geological Formations Likely To Be Used for Sequestration}

Data on the chemical composition of saline ground water was obtained from the Kansas Geological Survey which maintains a large dataset in partnership with NETL for the NatCarb database. The raw data set contains over 125,000 data records, including much of the data from the USGS produced water database (http://energy.cr.usgs.gov/prov/prodwat/data2.htm).

This data set was cross-referenced with the saline formations identified in the previous section to evaluate the brines that would likely be encountered during carbon sequestration. This resulted in a smaller data set containing around 41,000 samples, including at least one data point for 61 of the 99 total identified basins and formations. Samples taken at depths shallower than 2,500 ft were not included in this trimmed data set, except where no other data points were available for a specific formation. The 2,500-ft depth limit was selected to eliminate data points at depths that do not meet the pressure requirements for successful carbon sequestration (Kobos et al. 2009).

The trimmed data set was reviewed and analyzed to help understand the typical conditions that may be encountered in deep saline formations used for carbon sequestration. Brine characteristics discussed here include $\mathrm{pH}$, total dissolved solids (TDS), and concentrations of several other individual chemical constituents. It should be noted that throughout this section, units of $\mathrm{mg} / \mathrm{L}$ are used instead of ppm. Both units are commonly used when discussing water composition and quality and can be used interchangeably when the density of a fluid is one. However, as density diverges from one, as is the case in highly saline brines, the use of $\mathrm{mg} / \mathrm{L}$ is more appropriate.

\subsection{Data About pH and TDS}

Two important factors determining treatment requirements for produced or extracted water are $\mathrm{pH}$ and TDS. The graph shown in Figure 1 represents the distribution of the median $\mathrm{pH}$ across all the formations for which data was available. The $\mathrm{pH}$ appears to be roughly normally distributed around a mean between 7 and 7.5. While not shown here, further analysis of the data found that for individual formations there is a spread of approximately two units on the $\mathrm{pH}$ scale between the $5^{\text {th }}$ and $95^{\text {th }}$ percentiles. The median $\mathrm{pH}$ values for specific formations are listed in the table in appendix A. 


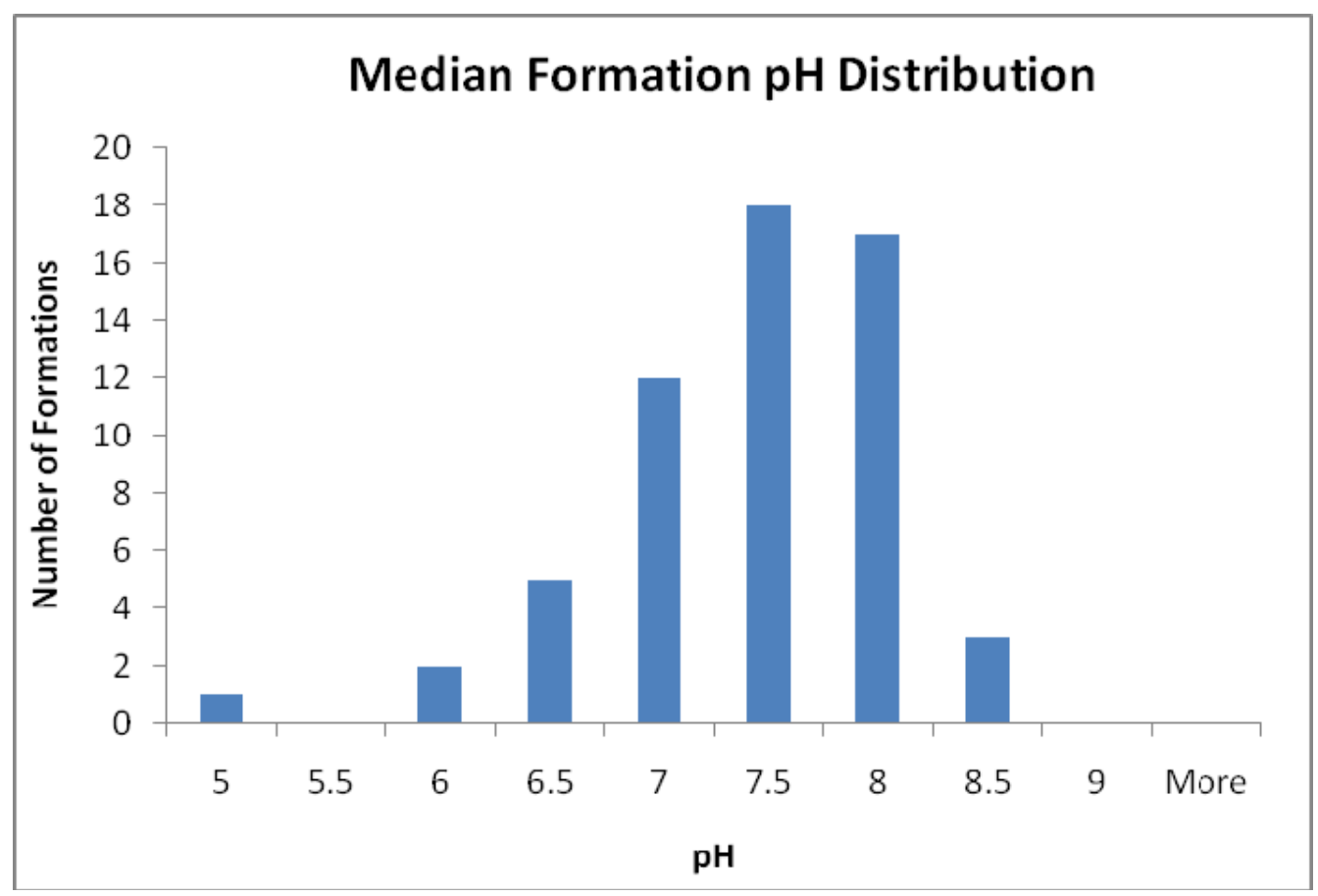

FIGURE 1 Histogram of Median Formation pH. The number on the horizontal axis of the graph for each bin represents the upper limit of the bin. The lower limit of the bin is equal to the upper limit of the bin to the left.

The concentration of TDS is a key parameter determining the feasibility of a number of water treatment technologies. In general, treatment becomes more difficult and expensive as TDS increases. Variation in this parameter was explored both by looking at the distribution of the median TDS for all formations in Figure 2 and further by producing box plots representing the distribution of TDS within each individual formation. These plots are grouped based upon the NETL carbon sequestration partnership regions and are shown in Figures 3 to 7.

When compared to $\mathrm{pH}$, the distribution of TDS is less easily defined. Median values range from less than $5,000 \mathrm{mg} / \mathrm{L}$ to over $300,000 \mathrm{mg} / \mathrm{L}$. The distribution is more heavily weighted toward the low end, with $59 \%$ of the formations having a value less than 40,000 mg/L. However, the distribution also has an elongated tail at the high end, with $15 \%$ of the formations having TDS of greater than 160,000 mg/L. Extracted water from these formations will be particularly challenging to treat. It should also be noted that formations with TDS below 10,000 $\mathrm{mg} / \mathrm{L}$ may face regulatory challenges.

The U.S. Environmental Protection Agency (EPA) defines underground sources of drinking water (USDW) as aquifers having TDS of less than 10,000 mg/L. According to the final regulations adopted on December 10, 2010 by the EPA [75 FR 77230], $\mathrm{CO}_{2}$ may not be injected into or above the lowermost USDW. The new section 40 CFR 146.95 outlines a waiver mechanism from the depth requirement to inject only below the lowermost USDW. To obtain a waiver, an owner or an operator of the injection well must prepare a demonstration that is subsequently approved by the state or U.S. EPA director. 


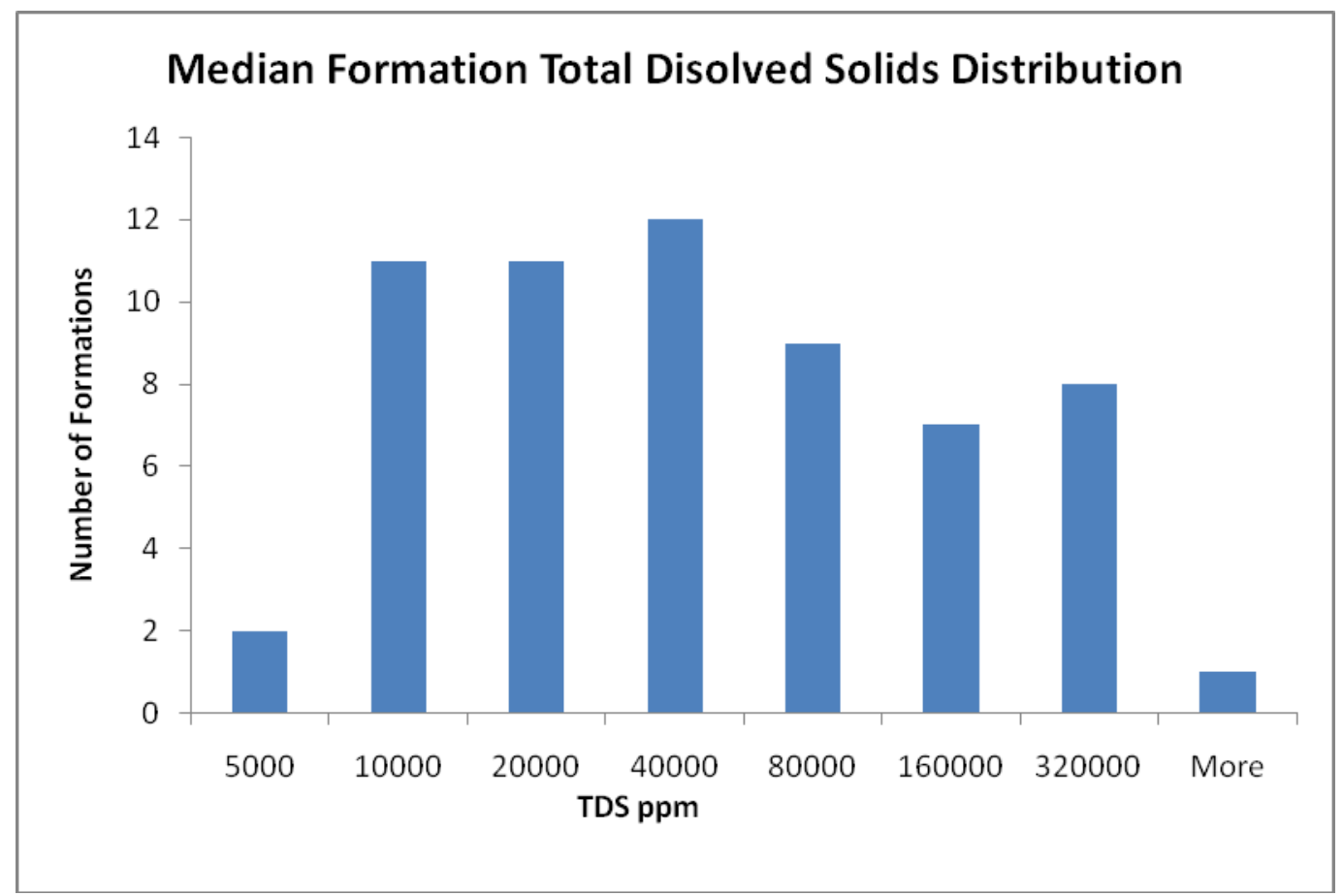

FIGURE 2 Histogram of Median Formation TDS. The number on the horizontal axis of the graph for each bin represents the upper limit of the bin. The lower limit of the bin is equal to the upper limit of the bin to the left. The scale on the axis is $\log$ base 2 .

The box plots show that TDS not only varies significantly between formations but that it can also vary quite a bit within the same formation. This indicates that water management practices will likely have to be tailored not just to individual formations, but also to specific project sites within a given formation. General regional trends are hard to pinpoint, although it does appear that the Midwest (MRCSP and MGSC partnerships) contains many of the formations with the highest TDS, while the Northwest (PCOR and Big Sky partnerships) contains a number of the formations with the lowest TDS. This is an encouraging trend, given that the estimated sequestration capacities of formations within the Big Sky and PCOR regions are about an order of magnitude greater than those in the MRCSP and MGSP regions. The region with the highest estimated sequestration capacity, SECARB, has TDS values that mostly fall in the middle of the range, with median values between 20,000 and 60,000 (with one exception). While the data provided in Figures 3 to 7 can provide rough screening for which regions and specific formations may be most suitable for specific water management practices, decisions on specific projects will depend on thorough characterization of local conditions. 


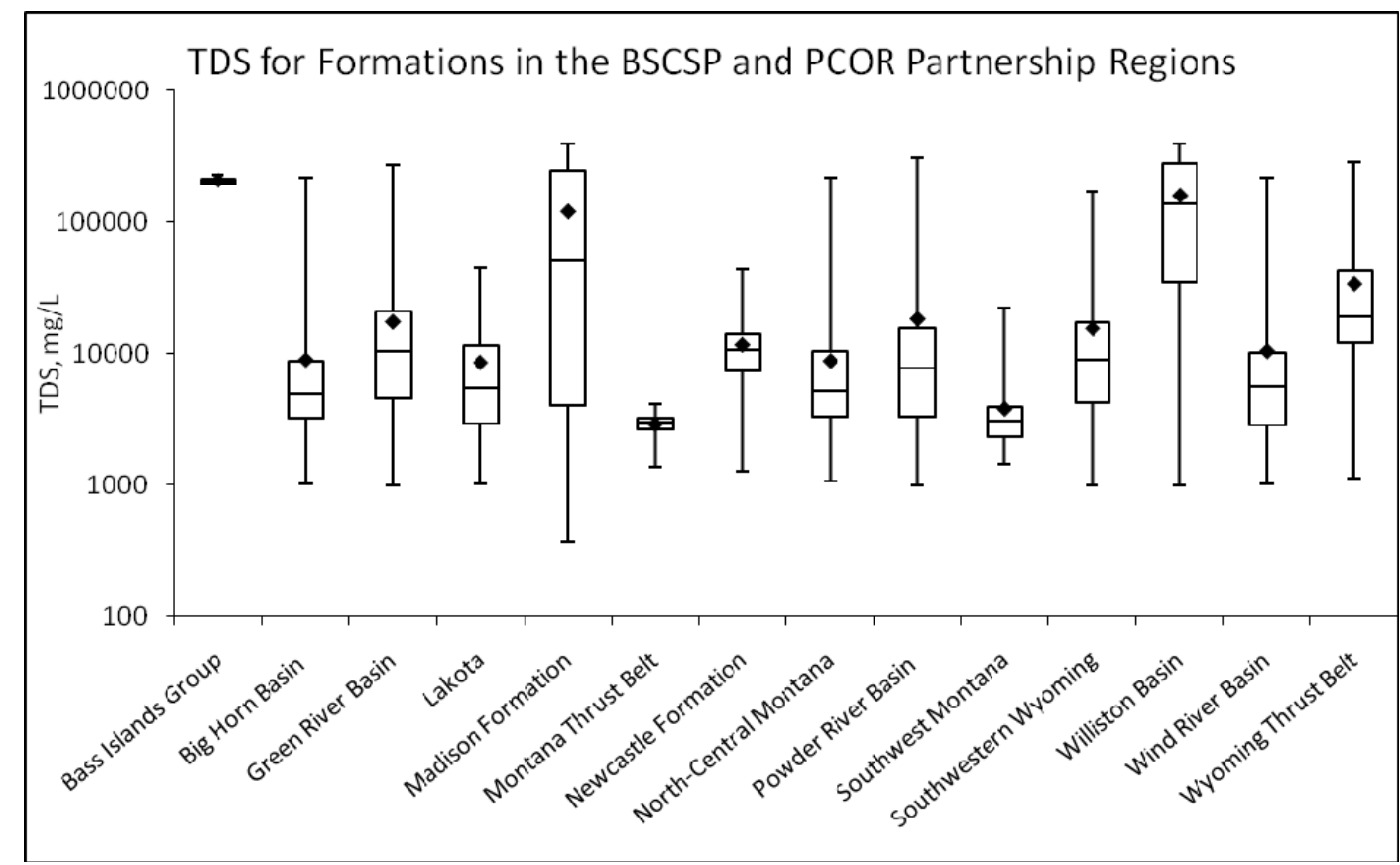

FIGURE 3 Box plot of TDS for formations in the BSCSP and PCOR partnership regions. The box represents the $25^{\text {th }}$ and $75^{\text {th }}$ percentiles, the line represents the median, the whiskers represent the minimum and maximum of the data, and a diamond indicates the mean.

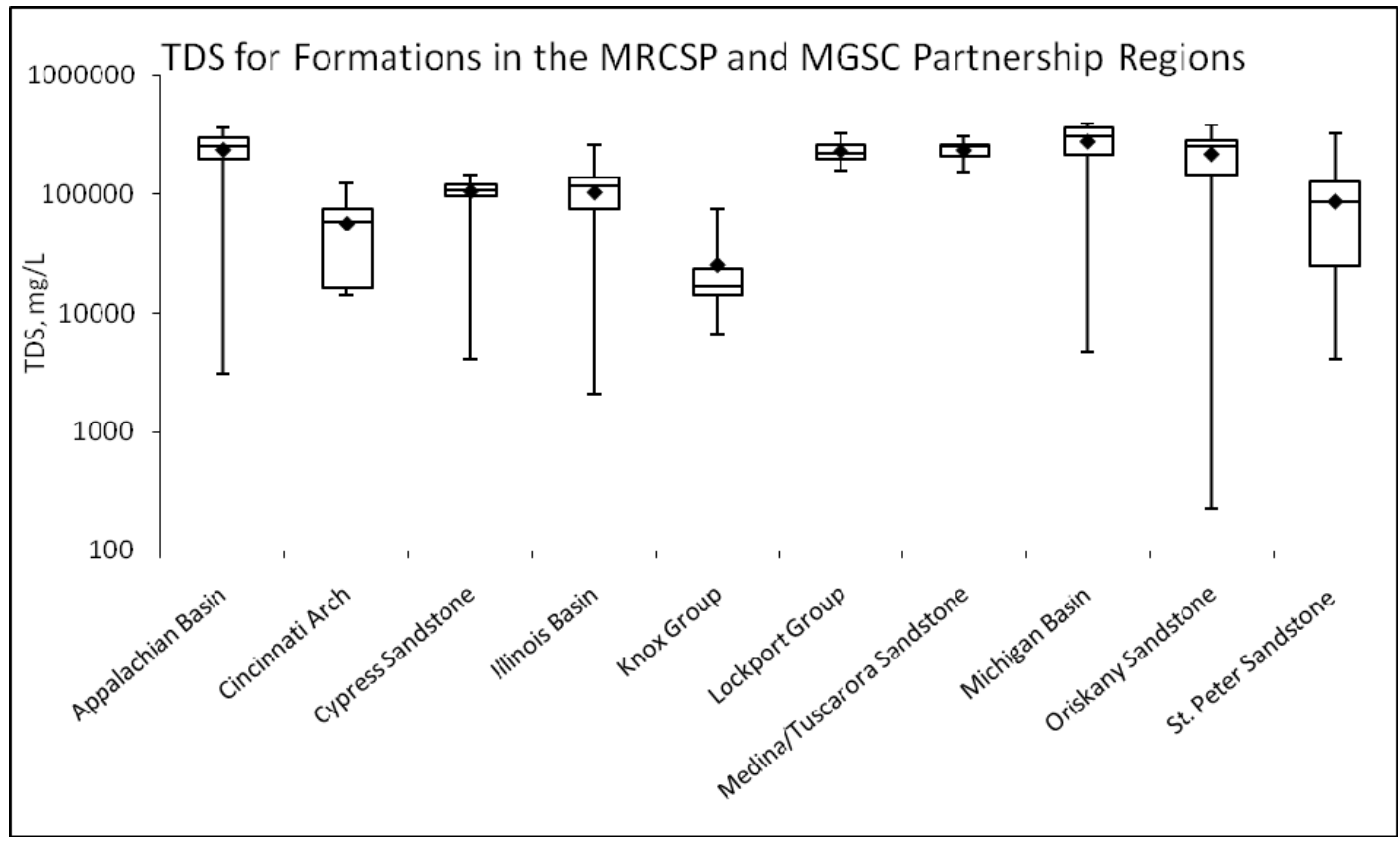

FIGURE 4 Box plot of TDS for formations in the MRCSP and MGSC partnership regions. The box represents the $25^{\text {th }}$ and $75^{\text {th }}$ percentiles, the line represents the median, the whiskers represent the minimum and maximum of the data, and a diamond indicates the mean. 


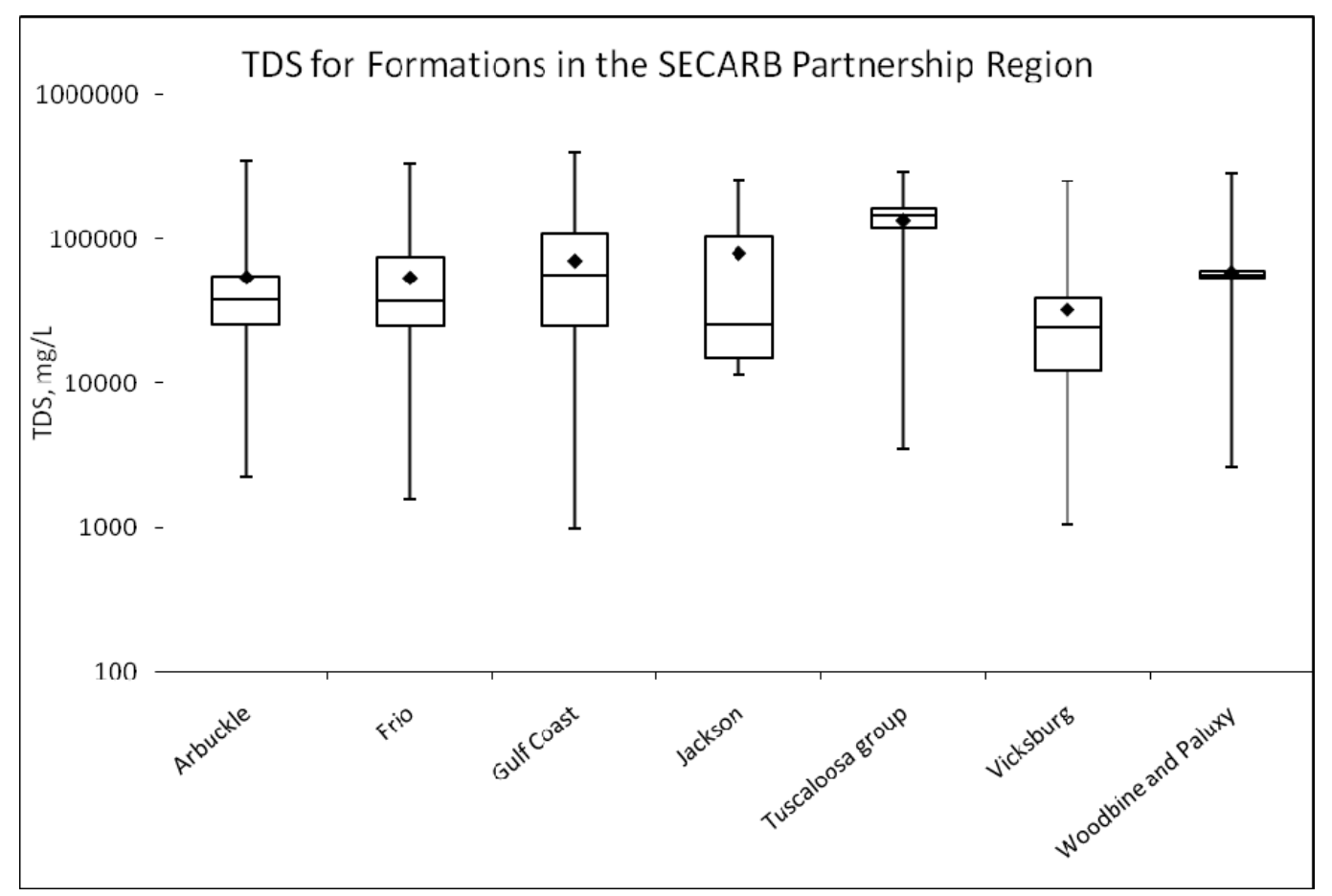

FIGURE 5 Box plot of TDS for formations in the SECARB partnership region. The box represents the $25^{\text {th }}$ and $75^{\text {th }}$ percentiles, the line represents the median, the whiskers represent the minimum and maximum of the data, and a diamond indicates the mean.

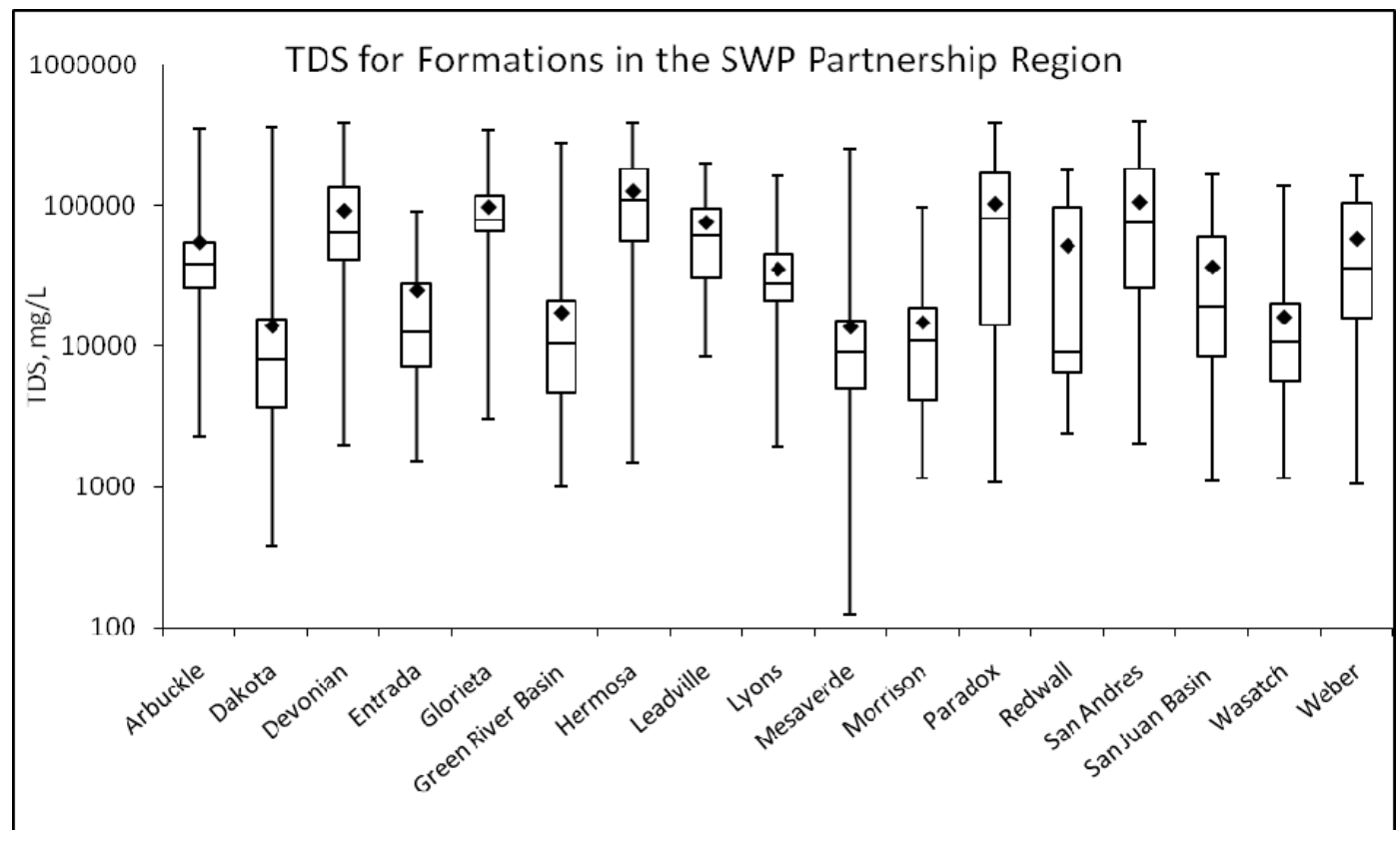

FIGURE 6 Box plot of TDS for formations in the SWP partnership region. The box represents the $25^{\text {th }}$ and $75^{\text {th }}$ percentiles, the line represents the median, the whiskers represent the minimum and maximum of the data, and a diamond indicates the mean. 


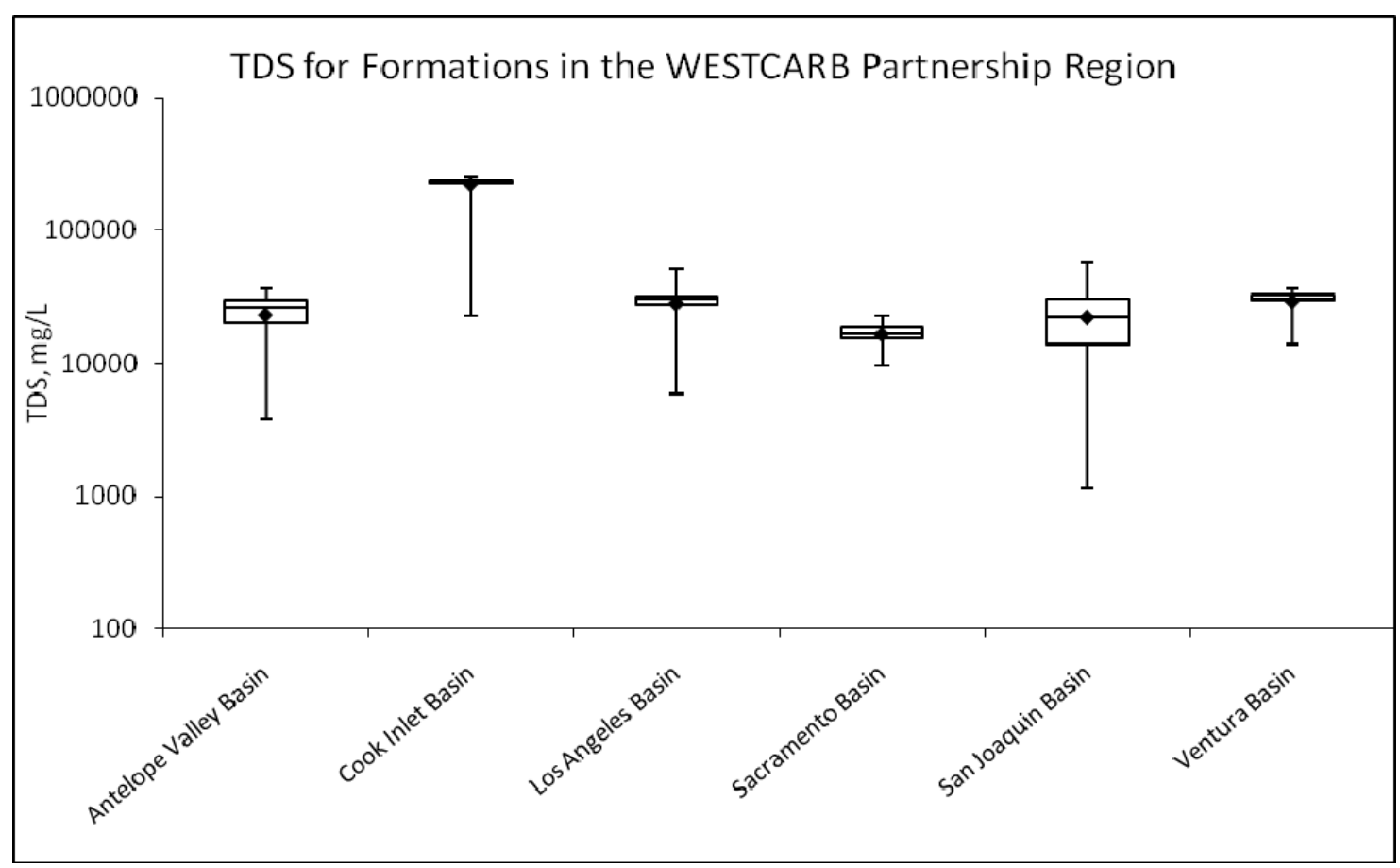

FIGURE 7 Box plot of TDS for formations in the WESTCARB partnership region. The box represents the $25^{\text {th }}$ and $75^{\text {th }}$ percentiles, the line represents the median, the whiskers represent the minimum and maximum of the data, and a diamond indicates the mean.

\subsection{Data About Other Chemical Constituents}

In addition to $\mathrm{pH}$ and TDS, the data set contains concentrations of other specific chemical constituents. However, these data are less complete, with many records only including values for a few of the dozens of possible constituents. For this reason, all data for each individual constituent were aggregated across formations. Figures 8 and 9 are box plots representing the distribution of ion concentrations. Figure 8 represents the constituents with the highest concentrations, while Figure 9 represents the constituents with lower concentrations. 


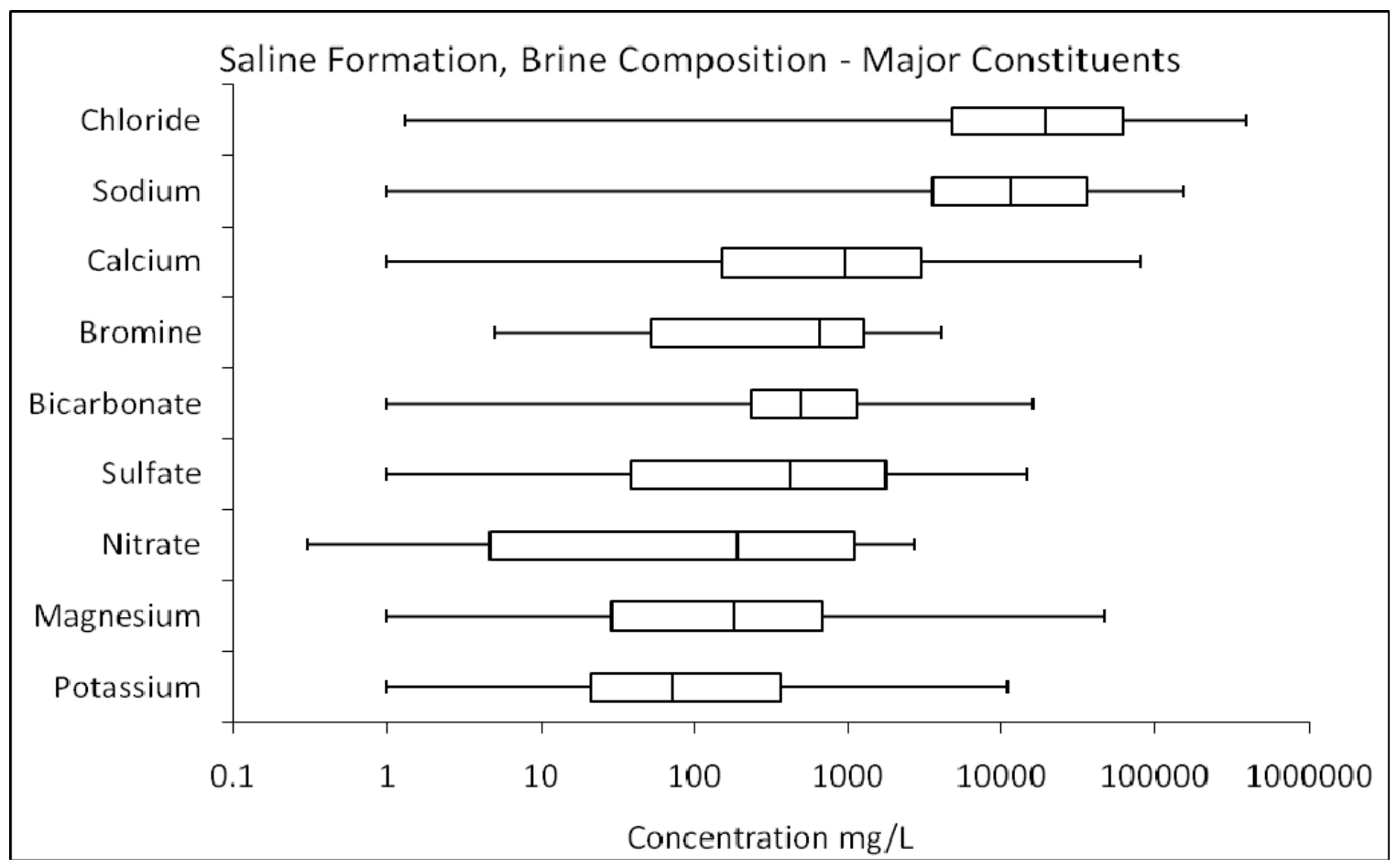

FIGURE 8 Brine Composition - Major Constituents across formations

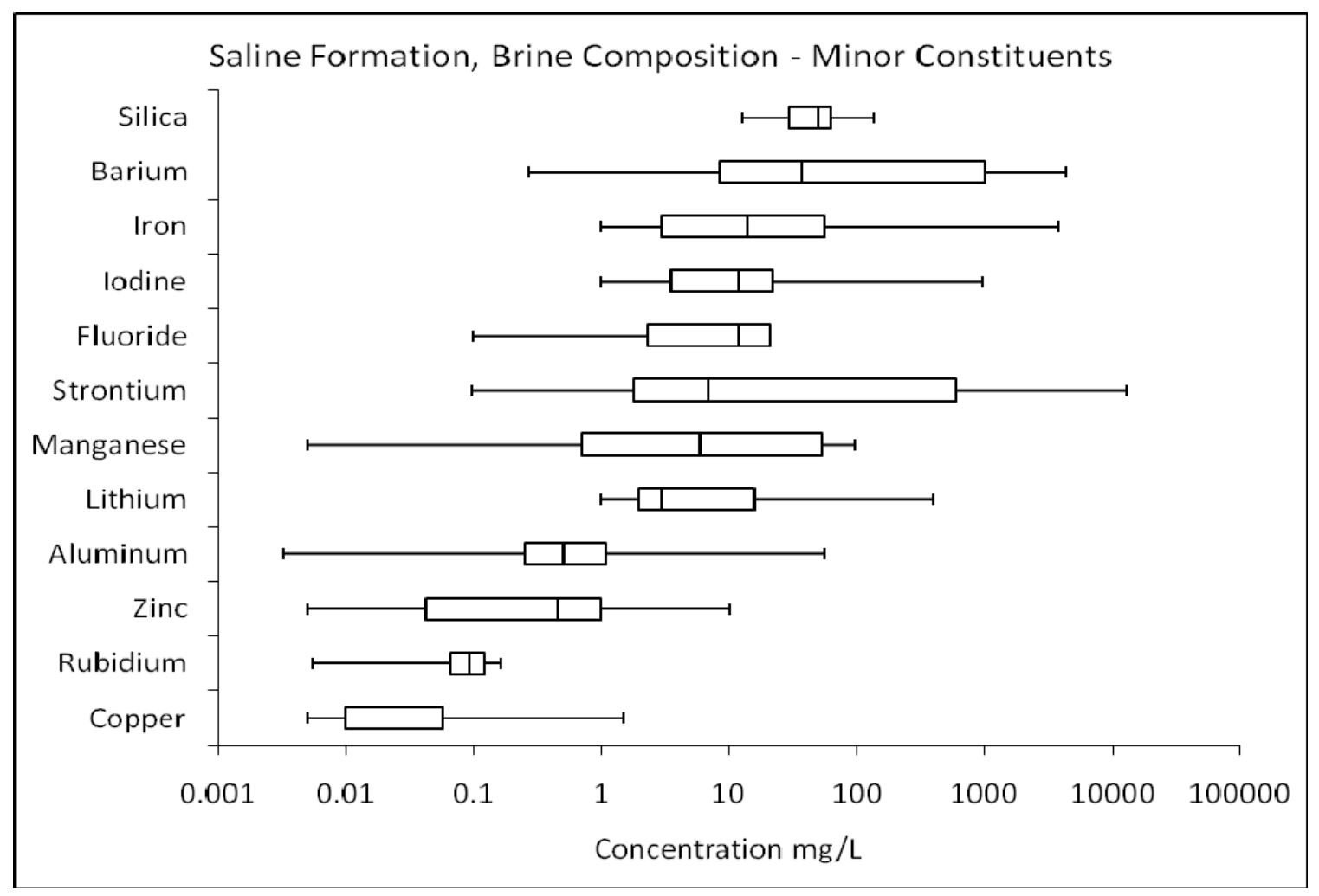

FIGURE 9 Brine Composition - Minor Constituents across formations 
There is clearly a significant spread in the concentrations of individual ions across the different formations. However, the concentrations, at least for the more common elements, tend to scale somewhat linearly with TDS. By looking at the data, a rough classification scheme was developed and is shown in Table 2. The scheme, as devised, has four tiers that represent ranges of typical concentrations. The top tier includes only elements with typical concentrations above $10,000 \mathrm{mg} / \mathrm{L}$ while the bottom tier contains elements with typical concentrations below $1 \mathrm{mg} / \mathrm{L}$.

Looking at Figures 8 and 9 and Table 2 it is clear that the vast majority of brines are dominated by sodium chloride. Other common constituents grouped into the second tier include sulfate, magnesium, nitrate, potassium, calcium, bromine, and bicarbonate. It should be noted that while a large number of data points were available for these more common ions, there was significantly less data for many of the minor constituents. Specifically, the distributions for copper, fluoride, nitrate, and zinc each contain 20 or fewer data points. Because of this, care should be taken in drawing broad conclusions based upon these specific concentrations.

To provide context to the chemical constituent concentrations, they were compared with both the primary and secondary national drinking water standards for inorganic contaminants. Table 3 provides a comparison with primary drinking water standards based upon human health impacts. Table 4 provides a comparison with national secondary drinking water standards that account for aesthetic and cosmetic effects such as color and taste. Both tables include the drinking water standard limit, the mean concentration, the median concentration, the total number of samples that included data for that contaminant, and the fraction of all the samples in the data set that meet the drinking water standard.

TABLE 2 Brine Constituent Classification Scheme

\begin{tabular}{ccl}
\hline & Typical & \\
Classification & Concentration (mg/L) & \multicolumn{1}{c}{ Constituents } \\
\hline Tier 1 & $1000+$ & Sodium, chloride \\
Tier 2 & $100-1000$ & Sulfate, magnesium, nitrate, calcium, bromine, bicarbonate \\
Tier 3 & $1-100$ & Strontium, silica, manganese, potassium, lithium, iron, iodine, \\
& & fluoride, barium \\
Tier 4 & $<1$ & Zinc, rubidium, copper, aluminum \\
\hline
\end{tabular}

These two tables demonstrate that treatment will be required, especially for barium and TDS, before water extracted from most saline formations can be used as a drinking water source. The limited number of data points available for many of the primary drinking water standards precludes strong conclusions from being drawn about specific contaminants. 
TABLE 3 Comparison with National Primary Drinking Water Standards

\begin{tabular}{lcccccc}
\hline Constituent & $\begin{array}{c}\text { Limit }^{\mathrm{a}} \\
(\mathrm{mg} / \mathrm{L})\end{array}$ & Standard & $\begin{array}{c}\text { Mean } \\
(\mathrm{mg} / \mathrm{L})\end{array}$ & $\begin{array}{c}\text { Median } \\
(\mathrm{mg} / \mathrm{L})\end{array}$ & $\begin{array}{c}\text { Number of } \\
\text { Samples }\end{array}$ & $\begin{array}{c}\text { Fraction Meeting } \\
\text { Standard }\end{array}$ \\
\hline Antimony & 0.006 & MCL & - & - & 0 & - \\
Arsenic & 0.01 & MCL & - & - & 0 & - \\
Barium & 2 & MCL & 656 & 42.1 & 100 & 0.09 \\
Beryllium & 0.004 & MCL & - & - & - & - \\
Cadmium & 0.005 & MCL & - & - & 0 & - \\
Chromium & 0.1 & MCL & - & - & 0 & - \\
Copper & 1.3 & TTC & 0.23 & 0.01 & 16 & 0.91 \\
Cyanide & 0.2 & MCL & - & - & 0 & - \\
Fluoride & 4 & MCL & 11.3 & 12.0 & 4 & 0.35 \\
Lead & 0.015 & TT & 0.025 & 0.02 & 6 & 0.00 \\
Mercury & 0.002 & MCL & - & - & 0 & - \\
Nitrate & 10 & MCL & 731 & 188 & 6 & 0.32 \\
Nitrite & 1 & MCL & - & - & 0 & - \\
Selenium & 0.05 & MCL & - & - & 0 & - \\
Thallium & 0.002 & MCL & - & - & 0 & - \\
\hline
\end{tabular}

a Source: USEPA (2010a).

b Maximum contaminant level allowed for drinking water.

c Regulated by a treatment technique; beyond this action level, additional steps must be taken to control these contaminants.

TABLE 4 Comparison with National Secondary Drinking Water Standards (NSDWRs)

\begin{tabular}{lcccccc}
\hline Constituent & $\begin{array}{c}\text { Limit } \\
(\mathrm{mg} / \mathrm{L})\end{array}$ & Standard & $\begin{array}{c}\text { Mean } \\
(\mathrm{mg} / \mathrm{L})\end{array}$ & $\begin{array}{c}\text { Median } \\
(\mathrm{mg} / \mathrm{L})\end{array}$ & $\begin{array}{c}\text { Number of } \\
\text { Samples }\end{array}$ & $\begin{array}{c}\text { Fraction Meeting } \\
\text { Standard }\end{array}$ \\
\hline Aluminum & 0.2 & NSDWR & 2.06 & 0.51 & 42 & 0.23 \\
Chloride & 250 & NSDWR & 36,000 & 13,600 & 41,295 & 0.08 \\
Iron & 0.3 & NSDWR & 96.8 & 13.0 & 326 & 0.06 \\
Manganese & 0.05 & NSDWR & 29.68 & 6.00 & 18 & 0.14 \\
Silver & 0.1 & NSDWR & - & - & 0 & - \\
Sulfate & 250 & NSDWR & 1,291 & 510 & 39,569 & 0.41 \\
Zinc & 5 & NSDWR & 1.78 & 0.46 & 16 & 0.88 \\
TDS & 500 & NSDWR & 61,176 & 24,601 & 40,356 & 0.00 \\
pH & $6.5-8.5$ & NSDWR & 7.3 & 7.4 & 35,621 & 0.74 \\
\hline
\end{tabular}

a Source: USEPA (2010a). 


\section{EXTRACTED WATER QUANTITY ESTIMATES}

To understand the potential feasibility of extracting water from receiving formations, the quantity of water that would need to be managed was estimated and compared to volumes of produced water currently being managed by the oil and gas industry. The estimates presented are first order estimates and are based upon a number of simplifying assumptions. The most important key assumption is that a volume of water equal to the volume of $\mathrm{CO}_{2}$ injected would be extracted to maintain a constant average formation pressure. The density of $\mathrm{CO}_{2}$ also varies significantly at different temperatures and pressures. This is illustrated in Figure 10. For these estimates $\mathrm{CO}_{2}$ density values of 0.65 to $0.78 \mathrm{~g} / \mathrm{cm}^{3}$ were used (Bentham and Kirby 2005 and Kobos et al. 2009). Using these assumptions, 1,300 to $1,500 \mathrm{~L}$ of water could be extracted and managed for every metric ton of $\mathrm{CO}_{2}$ sequestered. In alternate units this is 8.1 to 9.5 barrels of water ( 1 barrel $=42$ gallons) with an average of 8.8 barrels per metric ton of $\mathrm{CO}_{2}$.

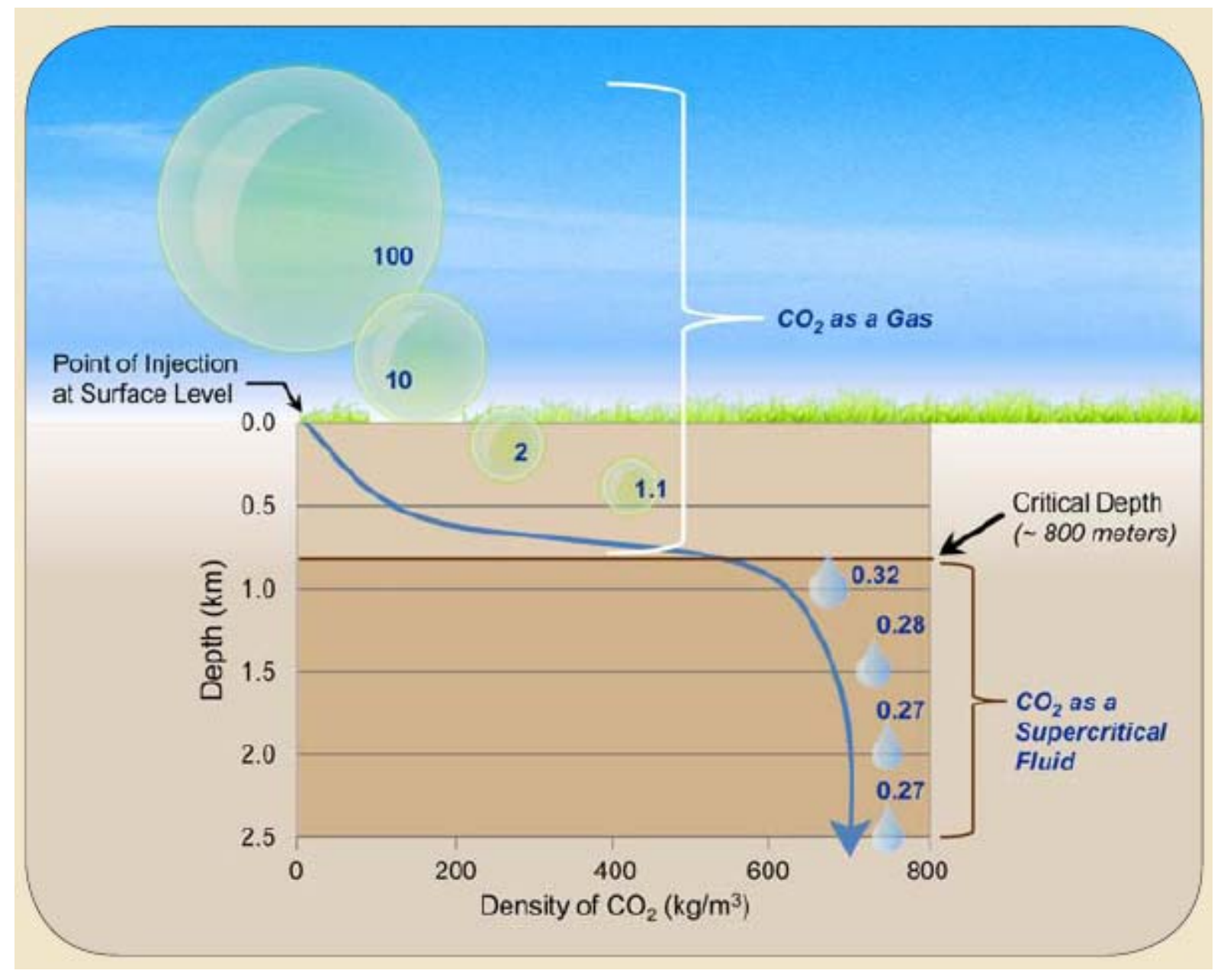

FIGURE 10 Illustration of $\mathrm{CO}_{2}$ Density Variation with Depth. Density is displayed on the $\mathrm{x}$-axis of the graph, while the relative volume occupied by the $\mathrm{CO}_{2}$ at different depths is illustrated with bubbles/water droplets of varying sizes with numerical values indexed to 100. (NETL 2010) 
Clark and Veil (2009) estimated that approximately 21 billion barrels of water were produced from almost 1 million active oil and gas wells in the United States in 2007. Based upon the EPA's most recent complete greenhouse gas inventory, the United States emitted 5.9 billion metric tons of $\mathrm{CO}_{2}$ in 2008 (EPA 2010b). Assuming at some point in the future carbon capture and sequestration (CCS) is scaled up to be equivalent to $10 \%$ of 2008 emissions and an equivalent volume of water is extracted to the volume of $\mathrm{CO}_{2}$ sequestered, this would require that about 5 billion barrels of water would need to be extracted and managed per year. This is about one-fourth of the water volume currently managed by the oil and gas industry.

Management of an incremental 25\% of water could pose challenges, particularly if the extracted water is located in regions that do not have suitable formations to receive saline water through injection wells. The exact volume of water that will eventually need to be managed will depend on a large number of variables including the:

- market penetration of CCS technology,

- cost of selected water management options,

- demand for water,

- specific receiving formation characteristics, and

- operating conditions determined by individual operators. 


\section{WATER MANAGEMENT TECHNOLOGIES AND PRACTICES}

The characteristics of produced water vary by location and over time. Different locales have different climates, regulatory or legal structures, and degrees of existing infrastructure. As a result, no single treatment technology is used at all locations. Many different technology options are available that can be employed at specific locations. Selection of a management option for produced water at a particular site varies, depending on the:

- chemical and physical properties of the water;

- $\quad$ volume, duration, and rate of water generation;

- desired end use or disposition of the water;

- treatment and disposal options allowed by state and federal regulations;

- technical and economical feasibility of any particular option, including transportation and logistics;

- availability of suitable infrastructure for disposal;

- willingness of companies to employ a particular technology or management option, including their concerns about potential liability; and

- cost involved with meeting the requirements and restrictions set by the regulatory agency.

Likewise, extracted water will vary in chemical and physical properties from location to location. The options that can be employed for managing the extracted water will depend on the same set of factors that are listed above for produced water.

Argonne has extensive experience in evaluating management of produced water from oil and gas wells (Veil et al. 2004; Clark and Veil 2009). In 2007, Argonne created the Produced Water Management Information System (PWMIS) website, now housed on DOE's website at http://www.netl.doe.gov/technologies/PWMIS/. PWMIS provides separate fact sheets on 25 different produced water management practices and technologies in the Technology

Description module (with several more fact sheets scheduled for addition in early 2011). As both produced water and extracted water are typically brackish or saline, many of the management practices used for produced water management may be applicable to extracted water. Most of the technologies and practices described in the following section have fact sheets in PWMIS that can be consulted for additional information.

Although many of the produced water management options described in PWMIS can be applied equally well to extracted water, some produced water practices may not make sense. For example, the two technologies described for keeping produced water from entering a well as a 
form of water minimization (i.e., shut off chemicals and mechanical blocking devices) make great sense for managing produced water but would be counterproductive for extracted water. In the latter case, the goal is to remove water from a formation that will be used for sequestration to make available more pore space.

\subsection{Water Management Hierarchy for Evaluation of Management Technologies and Options}

Extracted water management technologies and strategies can be described in terms of a three-tiered water management or pollution prevention hierarchy (i.e., minimization, recycle/reuse, and disposal). Examples of technologies and practices for each group are shown in Tables 5-9.

\subsubsection{Tier 1 - Minimization}

In the water-minimization tier, processes are modified, technologies are adapted, or products are substituted so that less water is generated. When feasible, water minimization can save money for operators and it results in greater protection of the environment. An example of a water minimization approach and technology is shown in Table 5.

TABLE 5 Water Minimization Technology for Extracted Water

\begin{tabular}{clll}
\hline \multicolumn{1}{c}{ Approach } & \multicolumn{1}{c}{ Technology } & \multicolumn{1}{c}{ Pros } & \multicolumn{1}{c}{ Cons } \\
\hline $\begin{array}{l}\text { Avoid handling } \\
\text { extracted water } \\
\text { at the surface. }\end{array}$ & $\begin{array}{l}\text { Pump extracted water } \\
\text { directly to another } \\
\text { disposal formation } \\
\text { without ever bringing } \\
\text { the water to the } \\
\text { surface. }\end{array}$ & $\begin{array}{l}\text { If a suitable disposal formation } \\
\text { is nearby and has adequate } \\
\text { capacity to take the water, this } \\
\text { could be a low-cost alternative. }\end{array}$ & $\begin{array}{l}\text { Need to have the right formation(s) } \\
\text { located nearby. Need to make sure } \\
\text { that the extracted-water chemistry } \\
\text { is compatible with the injection- } \\
\text { formation water to avoid forming } \\
\text { precipitants or undesirable } \\
\text { chemicals. Could compete with } \\
\text { formation space for disposing } \\
\text { produced water. }\end{array}$ \\
\hline
\end{tabular}

\subsubsection{Tier 2 - Recycle and Reuse}

For the extracted water that remains following water minimization, operators move next to the second tier, where water is reused in a beneficial manner or recycled. The most common way to reuse produced water is to reinject it into a producing formation to enhance production. Reinjection for enhanced recovery occurs in tens of thousands of injection wells throughout the United States (Clark and Veil 2009). Injection for enhanced recovery could also be a good management option for extracted water. 
Water is a scarce commodity in many parts of the world. Substantial efforts are ongoing to develop economical methods to treat produced water, most of which is quite salty, and put it to a new use. Some produced water, particularly the water associated with coalbed methane production in the Rocky Mountain region of the United States, has low salinity (EAA 2006). That water may be suitable for reuse without any treatment. This is unlikely to be the case with extracted water from CCS operations, as demonstrated in Figures 2 through 7. It may not make sense to expend high amounts of energy to treat very salty produced water, when a smaller amount of energy could be used more efficiently to treat an alternative water source (i.e., treated municipal wastewater, brackish ground water, and maybe even seawater, depending on the quality of the produced water). A similar situation applies to extracted water; it could serve as source water for many uses as long as the cost of treating and transporting the water is not prohibitive. Examples of water reuse and recycle management options as well as some of the specific uses are shown in Table 6.

\subsubsection{Tier 3 - Disposal}

When water cannot be managed through minimization, reuse, or recycling, operators must dispose of it. Table 7 lists water disposal technologies that could be employed for extracted water.

Prior to disposing of or reusing water, operators may need to employ different treatment processes and technologies. The final disposition of the water determines the type and extent of treatment. Treatment technologies can be divided into two general categories, technologies for removing salt and other inorganics and technologies for removing oil and grease. Table 8 lists treatment technologies designed to remove salt and other inorganics from produced water. Most of the formations from which water could be extracted are likely to require some treatment for removing TDS, salt, and other inorganic chemicals.

Table 9 lists treatment technologies designed to remove oil and grease and other organics from produced water. Since more of the storage resources for sequestration is in deep saline formations rather than hydrocarbon-producing formations, the levels of oil and grease and other organics are likely to be considerably lower than what is found in produced water when saline formations are used. Nevertheless, these technologies are listed here, since $\mathrm{CO}_{2}$ storage is also anticipated in depleting or depleted oil and gas formations and unmineable coal seams.

\subsection{Use of Extracted Water for Secondary Purposes}

Another potential future opportunity for deriving value from extracted water is to use the material for purposes other than just as water. Two ways in which extracted water can be used again are for geothermal power generation and as a feedstock for desirable mineral products. 
TABLE 6 Water Reuse and Recycle Management Options for Extracted Water

\begin{tabular}{|c|c|c|c|}
\hline $\begin{array}{c}\text { Management } \\
\text { Option }\end{array}$ & Specific Use & Pros & Cons \\
\hline $\begin{array}{l}\text { Reinjection } \\
\text { for enhanced } \\
\text { recovery }\end{array}$ & $\begin{array}{l}\text { Water flood; steam } \\
\text { flood; SAGD (steam } \\
\text { assisted gravity } \\
\text { drainage) for oil } \\
\text { sands }\end{array}$ & $\begin{array}{l}\text { Commonly used for produced } \\
\text { water for onshore wells. May } \\
\text { be a way to defray some } \\
\text { project costs if the oil and gas } \\
\text { company currently pays for } \\
\text { their water. }\end{array}$ & $\begin{array}{l}\text { Need to ensure chemical compatibility } \\
\text { with receiving formation. } \\
\text { Need to have a hydrocarbon-producing } \\
\text { formation nearby. }\end{array}$ \\
\hline $\begin{array}{l}\text { Injection for } \\
\text { future water } \\
\text { use }\end{array}$ & $\begin{array}{l}\text { Aquifer storage and } \\
\text { recovery }\end{array}$ & $\begin{array}{l}\text { Great option when possible. } \\
\text { Only one known example for } \\
\text { produced water (Wellington, } \\
\text { Colorado). }\end{array}$ & $\begin{array}{l}\text { May encounter public opposition. Will } \\
\text { require treatment to meet drinking } \\
\text { water standards prior to injection. }\end{array}$ \\
\hline \multirow{3}{*}{$\begin{array}{l}\text { Use for } \\
\text { hydrological } \\
\text { purposes }\end{array}$} & Subsidence control & $\begin{array}{l}\text { Can help solve a local problem } \\
\text { (e.g., Long Beach, California). }\end{array}$ & $\begin{array}{l}\text { Need to ensure chemical compatibility } \\
\text { with receiving formation. }\end{array}$ \\
\hline & $\begin{array}{l}\text { Saltwater intrusion } \\
\text { control }\end{array}$ & $\begin{array}{l}\text { Could be used as a barrier to } \\
\text { hold back saltwater intrusion } \\
\text { from coastal aquifers. }\end{array}$ & $\begin{array}{l}\text { Only likely to be applicable in coastal } \\
\text { areas. }\end{array}$ \\
\hline & $\begin{array}{l}\text { Stream flow } \\
\text { augmentation }\end{array}$ & $\begin{array}{l}\text { Where extracted water is } \\
\text { treated to allowable discharge } \\
\text { standards, it can help to } \\
\text { augment declining water } \\
\text { levels in streams. Some } \\
\text { interstate rivers are subject to } \\
\text { compacts that require } \\
\text { upstream states to provide a } \\
\text { minimum flow level for the } \\
\text { downstream states. }\end{array}$ & $\begin{array}{l}\text { Requires treatment to allowable } \\
\text { discharge standards. }\end{array}$ \\
\hline \multirow[t]{3}{*}{$\begin{array}{l}\text { Agricultural } \\
\text { use }\end{array}$} & $\begin{array}{l}\text { Irrigation; } \\
\text { subsurface drip } \\
\text { irrigation }\end{array}$ & $\begin{array}{l}\text { Could be a great benefit to } \\
\text { arid areas. }\end{array}$ & $\begin{array}{l}\text { May need to treat the water before } \\
\text { applying it to the soil or adding soil } \\
\text { supplements. }\end{array}$ \\
\hline & $\begin{array}{l}\text { Livestock and } \\
\text { wildlife watering }\end{array}$ & $\begin{array}{l}\text { Could provide a source of } \\
\text { water for animals. }\end{array}$ & $\begin{array}{l}\text { Need to ensure that water is clean } \\
\text { enough for animal consumption. }\end{array}$ \\
\hline & $\begin{array}{l}\text { Managed/ } \\
\text { constructed wetlands }\end{array}$ & $\begin{array}{l}\text { Provides a "natural” form of } \\
\text { treatment. Creates a good } \\
\text { habitat for wildlife. }\end{array}$ & $\begin{array}{l}\text { Large space requirements. Needs } \\
\text { extensive oversight and management. } \\
\text { Water may require some degree of } \\
\text { pretreatment prior to wetland } \\
\text { application. }\end{array}$ \\
\hline
\end{tabular}


TABLE 6 (Cont.)

\begin{tabular}{|c|c|c|c|}
\hline $\begin{array}{l}\text { Management } \\
\text { Option } \\
\end{array}$ & Specific Use & Pros & Cons \\
\hline \multirow[t]{4}{*}{ Industrial use } & $\begin{array}{l}\text { Oil and gas industry } \\
\text { applications }\end{array}$ & $\begin{array}{l}\text { Can substitute for fresh water } \\
\text { supplies in making new } \\
\text { drilling fluids or frac fluids. }\end{array}$ & $\begin{array}{l}\text { May need treatment to meet } \\
\text { operational specifications. Must have a } \\
\text { new well waiting to be drilled or } \\
\text { fracced so long-term water storage is } \\
\text { avoided. }\end{array}$ \\
\hline & Power plants & $\begin{array}{l}\text { May be able to supplement } \\
\text { cooling water sources. }\end{array}$ & $\begin{array}{l}\text { Will require treatment. The large } \\
\text { volumes needed for this use could } \\
\text { result in huge collection and } \\
\text { transportation costs, depending on the } \\
\text { distance between extraction wells and } \\
\text { power plants. }\end{array}$ \\
\hline & $\begin{array}{l}\text { Enhanced } \\
\text { geothermal power }\end{array}$ & $\begin{array}{l}\text { Enhanced geothermal systems } \\
\text { require water to stimulate the } \\
\text { formations and may require } \\
\text { additional water to make up } \\
\text { for water lost to the formation. } \\
\text { Limited treatment would be } \\
\text { needed. }\end{array}$ & $\begin{array}{l}\text { Need to ensure chemical compatibility } \\
\text { with receiving formation. } \\
\text { Need to have geothermal resources } \\
\text { nearby. }\end{array}$ \\
\hline & $\begin{array}{l}\text { Other (e.g., vehicle } \\
\text { wash, fire-fighting, } \\
\text { dust control on } \\
\text { gravel roads) }\end{array}$ & $\begin{array}{l}\text { Can be a good supplemental } \\
\text { water supply in arid areas. }\end{array}$ & $\begin{array}{l}\text { Will need storage facilities. Will } \\
\text { possibly need treatment. }\end{array}$ \\
\hline $\begin{array}{l}\text { Treat to } \\
\text { drinking } \\
\text { water quality }\end{array}$ & $\begin{array}{l}\text { Use for drinking } \\
\text { water and other } \\
\text { domestic uses }\end{array}$ & $\begin{array}{l}\text { Can help supply water to } \\
\text { communities in arid areas. }\end{array}$ & $\begin{array}{l}\text { Cost to treat may be high. Need good } \\
\text { quality control. May encounter public } \\
\text { opposition. Concern over liability. It } \\
\text { may be more cost-effective and } \\
\text { energy-conserving to treat other water } \\
\text { sources such as moderately saline } \\
\text { ground water rather than treating } \\
\text { highly saline extracted water. }\end{array}$ \\
\hline
\end{tabular}

\subsubsection{Geothermal Energy}

Geothermal energy is a renewable source of energy that utilizes heat generated within the earth. Geothermal energy can be used for heating buildings or for producing electricity. Geothermal power plants typically use hot ground water either directly as vapor or indirectly through a heat exchange process to create vapor. The vapor spins a turbine connected to a generator. In general, temperatures of at least $90^{\circ} \mathrm{C}$ and preferably greater than $150^{\circ} \mathrm{C}$, are desirable for utility scale geothermal energy production. At lower temperatures, geothermal energy can be used directly for heating and cooling, using geothermal heat pumps. They take 
TABLE 7 Water Disposal Technologies for Extracted Water

\begin{tabular}{|c|c|c|}
\hline Technology & Pros & Cons \\
\hline Discharge & $\begin{array}{l}\text { Offers moderate cost and acceptable } \\
\text { environmental impact, where permitted. }\end{array}$ & $\begin{array}{l}\text { Discharge of produced water is not } \\
\text { approved for most onshore wells. It is } \\
\text { unclear what regulatory discharge } \\
\text { standards will ultimately be applied to } \\
\text { extracted water. Where discharge is } \\
\text { allowed, treatment is required unless the } \\
\text { water is already of high quality. May } \\
\text { encounter public opposition. }\end{array}$ \\
\hline $\begin{array}{l}\text { Underground injection } \\
\text { (other than for enhanced } \\
\text { recovery); different } \\
\text { from the example in } \\
\text { Table } 6 \text { in that the water } \\
\text { would be pumped to the } \\
\text { surface first, treated if } \\
\text { necessary, then } \\
\text { reinjected }\end{array}$ & $\begin{array}{l}\text { Very common practice for onshore } \\
\text { produced water. Tends to have low cost. } \\
\text { EPA and state agencies recognize this as } \\
\text { a safe, widely used, proven, and effective } \\
\text { method for disposing of produced water. }\end{array}$ & $\begin{array}{l}\text { Requires the presence of an underground } \\
\text { formation with suitable porosity, } \\
\text { permeability, and storage capacity. May } \\
\text { require treatment to ensure that injectate } \\
\text { does not plug formation. }\end{array}$ \\
\hline Evaporation & $\begin{array}{l}\text { In arid climates, takes advantage of } \\
\text { natural conditions of humidity, sun, and } \\
\text { wind. }\end{array}$ & $\begin{array}{l}\text { Not practicable in humid climates. May } \\
\text { create air quality and salt deposition } \\
\text { problems. Could have large land } \\
\text { requirements. }\end{array}$ \\
\hline $\begin{array}{l}\text { Offsite commercial } \\
\text { disposal }\end{array}$ & $\begin{array}{l}\text { Many companies provide service to the } \\
\text { oil and gas community by accepting and } \\
\text { disposing produced water for a fee. The } \\
\text { same facilities also may be willing to take } \\
\text { extracted water. Removes water } \\
\text { management burden from the operator. }\end{array}$ & $\begin{array}{l}\text { Requires infrastructure (disposal } \\
\text { facilities and transportation network to } \\
\text { move water to disposal site). Can be } \\
\text { costly. Potential for Superfund liability. }\end{array}$ \\
\hline
\end{tabular}

advantage of relatively constant subsurface temperatures to significantly reduce heating and cooling loads (Duffield and Sass 2003).

Traditionally, geothermal energy developers seek out high-temperature formations and construct new high-volume extraction wells to withdraw the hot ground water. However, in recent years, interest has shifted to finding existing sources of ground water for which the wells are already drilled. If the cost of constructing a well has already been paid by another user, such as an oil and gas producer or a CCS project operator, the geothermal power producer can use water of a lower temperature and still produce electricity economically. With this in mind, attention has shifted to evaluating operating oil and gas wells as geothermal source wells.

The first actual example in which geothermal power was generated from a producing oil and gas well was a test conducted at DOE's Rocky Mountain Oilfield Technology Center in 
TABLE 8 Water Technologies for Removing Salt Content

\begin{tabular}{|c|c|c|c|}
\hline Technology & Subcategory & Pros & Cons \\
\hline \multirow[t]{2}{*}{$\begin{array}{l}\text { Membrane } \\
\text { processes }\end{array}$} & $\begin{array}{l}\text { Microfiltration, } \\
\text { ultrafiltration, } \\
\text { and } \\
\text { nanofiltration }\end{array}$ & $\begin{array}{l}\text { These are good pretreatment } \\
\text { steps for more advanced } \\
\text { processes such as reverse } \\
\text { osmosis. They operate at lower } \\
\text { pressure and lower cost than } \\
\text { reverse osmosis. }\end{array}$ & $\begin{array}{l}\text { These levels of filtration cannot remove } \\
\text { most salinity. Potential for membrane } \\
\text { fouling. Sensitivity to fluctuating water } \\
\text { quality. }\end{array}$ \\
\hline & $\begin{array}{l}\text { Reverse } \\
\text { osmosis }\end{array}$ & $\begin{array}{l}\text { Reverse osmosis can remove } \\
\text { salinity (up to about 50,000 } \\
\text { mg/L TDS). }\end{array}$ & $\begin{array}{l}\text { Requires pretreatment and regular } \\
\text { membrane cleaning. Not suitable for } \\
\text { high-salinity water. Potential for } \\
\text { membrane fouling. Sensitivity to } \\
\text { fluctuating water quality. }\end{array}$ \\
\hline \multirow[t]{2}{*}{$\begin{array}{l}\text { Thermal } \\
\text { treatment }\end{array}$} & Distillation & $\begin{array}{l}\text { Can process high-salinity waters. } \\
\text { Generate very clean water as one } \\
\text { product (can be reused). }\end{array}$ & $\begin{array}{l}\text { High-energy usage and cost. Generates } \\
\text { concentrated brine stream that requires } \\
\text { separate disposal. Potential for scaling. }\end{array}$ \\
\hline & $\begin{array}{l}\text { Evaporation/ } \\
\text { crystallization }\end{array}$ & $\begin{array}{l}\text { Can treat to a zero liquid } \\
\text { discharge standard. }\end{array}$ & $\begin{array}{l}\text { High-energy usage and cost. Limited } \\
\text { usage in oil field applications. Potential } \\
\text { for scaling. Challenges in disposing of } \\
\text { salt residue. }\end{array}$ \\
\hline Ion exchange & None & $\begin{array}{l}\text { Successfully treat low- to } \\
\text { medium-salinity water. }\end{array}$ & $\begin{array}{l}\text { Large acid usage. Resins can foul. } \\
\text { Challenges in disposing of rinse water } \\
\text { and spent media (resin). Also ineffective } \\
\text { on high-salinity produced waters. }\end{array}$ \\
\hline $\begin{array}{l}\text { Capacitive } \\
\text { deionization }\end{array}$ & None & Low energy cost. & $\begin{array}{l}\text { Limited to treating low-salinity waters. } \\
\text { Limited usage in oil-field applications, } \\
\text { but could have a role in treating extracted } \\
\text { water with low to medium TDS. }\end{array}$ \\
\hline
\end{tabular}

Wyoming. The test unit was a 250-kW Organic Rankine Cycle (ORC) power plant designed to use 40,000 bpd of $170^{\circ} \mathrm{F}$ produced water from the field's Tensleep Formation to vaporize the working fluid, isopentane. The projected gross power from the unit was $180 \mathrm{~kW}$ (net of $132 \mathrm{~kW}$ ). Because of the lack of sufficient cooling water for the system, an air-cooled unit was designed.

The unit was put into service in September 2008 and operated until February 2009, when the unit was shut down because of operational problems. During this period, the unit produced $586 \mathrm{MW}$-hr of power. The operational problems, caused by operating in excess of the unit capacity, resulted in changes in the control system and repairs to the generator and turbine system. The unit was restarted in September 2009. Between September 2009 and the end of February 2010, the unit produced $478 \mathrm{MW}$-hr of power at a more consistent rate than before the extended shutdown (Johnson and Walker 2010). 


\section{TABLE 9 Water Technologies for Removing Oil and Grease Content}

\begin{tabular}{|c|c|c|c|}
\hline Technology & Subcategory & Pros & Cons \\
\hline \multirow[t]{4}{*}{$\begin{array}{l}\text { Physical } \\
\text { separation }\end{array}$} & $\begin{array}{l}\text { Advanced } \\
\text { separators (e.g., } \\
\text { inclined plate, } \\
\text { corrugated plate) }\end{array}$ & $\begin{array}{l}\text { Provide enhanced oil capture } \\
\text { compared to basic oil or water } \\
\text { separators }\end{array}$ & $\begin{array}{l}\text { Works well for free oil, but not as } \\
\text { effective on dispersed and soluble oil. } \\
\text { Performance can be improved by } \\
\text { adding flocculants. }\end{array}$ \\
\hline & Hydrocyclone & $\begin{array}{l}\text { No moving parts results in good } \\
\text { reliability. Separates free oil very } \\
\text { well. }\end{array}$ & $\begin{array}{l}\text { Does not work well on dispersed and } \\
\text { soluble oil. }\end{array}$ \\
\hline & Filtration & $\begin{array}{l}\text { Different types of filter media and } \\
\text { filter operations provide a good } \\
\text { range of oil and grease removal. }\end{array}$ & $\begin{array}{l}\text { Requires regular back-flushing. Does } \\
\text { not treat soluble oil. }\end{array}$ \\
\hline & Centrifuge & $\begin{array}{l}\text { Provides good separation of free and } \\
\text { dispersed oil. }\end{array}$ & $\begin{array}{l}\text { More expensive than other } \\
\text { technologies in this group. }\end{array}$ \\
\hline Coalescence & None & $\begin{array}{l}\text { Collects small oil droplets and forms } \\
\text { larger droplets that can be more } \\
\text { easily removed by the other } \\
\text { technologies. }\end{array}$ & $\begin{array}{l}\text { Limited value for dispersed or soluble } \\
\text { oil. }\end{array}$ \\
\hline Flotation & $\begin{array}{l}\text { Dissolved air } \\
\text { flotation, } \\
\text { induced gas } \\
\text { flotation }\end{array}$ & Removes free and dispersed oil. & Does not remove soluble oil. \\
\hline Adsorption & $\begin{array}{l}\text { Organoclay, } \\
\text { activated carbon, } \\
\text { zeolites }\end{array}$ & $\begin{array}{l}\text { Does a good job at removing oil and } \\
\text { grease and other organic materials. } \\
\text { Used primarily for polishing. }\end{array}$ & $\begin{array}{l}\text { Media cannot be reused or } \\
\text { regenerated; results in large volume } \\
\text { of solid waste. }\end{array}$ \\
\hline
\end{tabular}

At this point, data on the temperatures of targeted deep saline formations appears to be limited. Without more data, it is difficult to assess the true geothermal potential of these aquifers. It is known that geothermal potential is the highest in western states, especially Nevada and California; and thus, these states are the most likely to contain deep saline formations that may also be useful for geothermal energy production (Duffield and Sass 2003).

\subsubsection{Extraction of Mineral Commodities}

Some chemicals are produced through solution mining, a process that involves the injection of water and other additives into a formation to dissolve soluble minerals. The mineralladen water is then pumped back to the surface, where the desired constituents are recovered. Solution mining is energy-intensive because of the need to inject and extract large volumes of 
liquid. If extracted water from a particular formation contains sufficient concentrations of desirable compounds, it can be a cost-effective feedstock. The chemical producer would not have to pay for the cost of injecting water and extracting the solution since it would already be at the surface as a result of formation-water extraction.

The concept of extracting saleable minerals from brines is not new, but it is regaining interest. One element that has already attracted attention as a possible by product is lithium. Over the past year, the DOE Office of Energy Efficiency and Renewable Energy awarded a large grant to a company that will develop and validate improved lithium extraction technologies from geothermal brines of varying salinity (USDOE 2011). Researchers in Brazil are also studying the economic feasibility of extracting sodium carbonate (sodium ash) from produced water (Grimaldi et al. 2010).

Clark et al. (2011) surveyed the historical literature on the extraction of minerals from geothermal brines. They identified at least 14 projects that attempted to economically produce a range of minerals from geothermal brines including, but not limited to: $\mathrm{Li}, \mathrm{Zn}, \mathrm{Mn}, \mathrm{Mg}, \mathrm{NaCl}$, $\mathrm{KCl}, \mathrm{CaCl}_{2}$, silica, and borax. Of these projects, very few were more than a temporary commercial success. Reasons for failure varied, but they included changes to underlying commodity prices and high operating costs resulting from high temperatures, scale and corrosion, and challenging separation processes due to complex brine chemistry. At least three newer projects are still in the early feasibility stages. Two are focused on lithium and one is focused on silica production.

Lehr et al. (1982) also surveyed mineral extraction from non-geothermal brines. They identified at least 35 projects of which at least 26 were commercial operations. The minerals extracted included I, $\mathrm{Br}, \mathrm{Li}, \mathrm{Mg}, \mathrm{NaCl}, \mathrm{KCl}, \mathrm{CaCl}_{2}, \mathrm{NaCO}_{3}$, and borax. A wide range of brine sources were used including produced water, seawater, groundwater, surface water bodies, and industrial wastewater. Unfortunately most of this data is over 30 years old, and few details are provided about these projects, so few conclusions can be drawn other than the fact that some minerals have been extracted commercially from some brines in the past.

The potential for mineral extraction from extracted water will be highly site specific. While it is possible and even likely that there will be formations that have favorable conditions for mineral extraction, these will more than likely be the exception rather than the rule, based upon the past history of mineral extraction from brines. The geochemical dataset obtained for this study is fairly limited on concentration values for many of the minerals that may be of interest. More data on these concentrations will be required before more formation-specific screening and analysis can be performed. 


\section{COST OF EXTRACTED WATER MANAGEMENT}

The cost of managing water will be an important factor in determining if it makes sense to extract water from a given formation. These costs will vary significantly depending upon the location, specific brine characteristics, and the management strategy selected. To get a better idea of what these costs might be, cost estimates were obtained for many existing oil and gas produced water management practices. Costs were obtained for both disposal options and treatment options that would allow for a wide range of beneficial uses. We note that it is challenging to find accurate and relevant published estimates for costs as both treatment providers and well operators are reluctant to share detailed cost information. Therefore, the cost estimates provided in this chapter should be considered as approximations. Further, the cited cost values in Tables 10 through 12 are taken from references published in different years. The value of a 1992 dollar is greater than the value of a 2006 dollar in current times. Readers are advised to use the cost figures in this chapter as a starting point, then do their own estimation and validation evaluation.

A summary of cost data for produced water disposal is shown in Table 10. The disposal methods for which data were available included discharge to a surface water body with a NPDES permit, injection underground to an underground injection control permitted disposal well, and evaporation in specially designed evaporation ponds. Discharge is generally the least expensive management practice, where available, with costs as low as a few cents per barrel in some locations. However, for commercial treatment and disposal, costs can exceed \$2/bbl. Permitting is likely to be a major hurdle to the use of surface discharge for managing extracted water due to the typically high concentration of dissolved solids. Injection is the most common disposal option for produced water. The costs can vary from a few cents all the way up to $\$ 10.00 / \mathrm{bbl}$, but more typical values are from $\$ 0.30$ to $\$ 2.00 / \mathrm{bbl}$. The wide variability in costs is due to differences in the geological properties of the formations chosen for injection as well as the transportation distance to the injection well. Evaporation is also a common disposal method in arid regions. Costs range from $\$ 0.05$ to $\$ 4.00 / \mathrm{bbl}$. Cost drivers include the cost of land, pond construction, and transportation.

Costs for water treatment for the removal of total dissolved solids are shown in Table 11. Costs are presented for three different treatment technologies including reverse osmosis (RO), thermal distillation, and capacitive deionization. Costs were somewhat lower for RO ( $\$ 0.45$ to $\$ 3.50 / \mathrm{bbl}$ ) and capacitive deionization $(\$ 1 / \mathrm{bbl})$, but these two technologies tend to have pretreatment costs that can increase significantly as TDS concentrations increase. RO is most economical at concentrations around 30,000 $\mathrm{mg} / \mathrm{L}$ and below, but becomes technically challenging with low recovery rates above 50,000 to 60,000 mg/L. Ongoing research at Lawrence Livermore National Laboratory has indicated that the costs of RO could be significantly reduced for water that is pressurized at the wellhead by the injection of $\mathrm{CO}_{2}$ into the formation (Wolery et al. 2009). The data obtained for thermal distillation systems indicate higher prices of $\$ 6.70$ and $\$ 8.45 / \mathrm{bbl}$, but these systems can more easily handle higher TDS concentrations. While lower recovery rates and higher concentrate disposal costs are expected, significant increases in the amount of energy required to treat water as TDS concentrations increase are not expected. 


\section{TABLE 10 Costs for Produced Water Disposal}

\begin{tabular}{|c|c|c|c|c|c|}
\hline State & Management Practice & Cost $/ \mathrm{bbl}^{\mathrm{a}}$ & $\begin{array}{c}\text { Transport } \\
\text { Cost } \\
\text { Included }\end{array}$ & Year & Source \\
\hline PA & Discharge & $\$ 2.90$ & $\mathrm{n}$ & 2010 & Quote $^{\mathrm{b}}$ \\
\hline PA & Discharge & $\$ 0.75-2.75$ & $\mathrm{n}$ & 2006 & Puder and Veil 2006 \\
\hline MT & Discharge & $\$ 0.02-0.10$ & $\mathrm{y}$ & 2006 & EEA 2006 \\
\hline MT, WY & Discharge and injection & $\$ 0.01-2.00$ & $\mathrm{y}$ & 2001 & Boysen et al. 2002 \\
\hline WY & Discharge and injection & $\$ 0.04-0.35$ & $\mathrm{y}$ & 1998 & Boysen et al. 2002 \\
\hline WY & Discharge, injection, evaporation & $\$ 0.01-0.10$ & $\mathrm{y}$ & 1998 & Boysen et al. 2002 \\
\hline MT & $\begin{array}{l}\text { Discharge, injection, evaporation, } \\
\text { commercial disposal }\end{array}$ & $\$ 0.05-2.00$ & $\mathrm{y}$ & 2001 & Boysen et al. 2002 \\
\hline MT & Injection and discharge & $\$ 0.02$ & $\mathrm{n}$ & 1998 & Boysen et al. 2002 \\
\hline MT & Injection & $\$ 1.26$ & $\mathrm{n}$ & 2006 & EEA 2006 \\
\hline $\mathrm{AL}$ & Injection & $\$ 0.80$ & ? & 1992 & Nakles et al. 1992 \\
\hline NM & Injection & $\$ 0.50-1.75$ & ? & 1992 & Nakles et al. 1992 \\
\hline $\mathrm{CO}$ & Injection & $\$ 1.00$ & $\mathrm{y}$ & 1998 & Boysen et al. 2002 \\
\hline $\mathrm{CO}$ & Injection & $\$ 0.05-0.70$ & $\mathrm{y}$ & 1998 & Boysen et al. 2002 \\
\hline $\mathrm{CO}$ & Injection & $\$ 0.50-1.50$ & $\mathrm{y}$ & 2000 & Boysen et al. 2002 \\
\hline $\mathrm{CO}$ & Injection & $\$ 0.06-1.50$ & $\mathrm{y}$ & 1998 & Boysen et al. 2002 \\
\hline $\mathrm{CO}$ & Injection & $\$ 0.30-2.80$ & $\mathrm{y}$ & 2001 & Boysen et al. 2002 \\
\hline NM & Injection & $\$ 0.50-4.20$ & $\mathrm{y}$ & 2001 & Boysen et al. 2002 \\
\hline UT & Injection & $\$ 0.04-2.00$ & $\mathrm{y}$ & 1998 & Boysen et al. 2002 \\
\hline UT & Injection & $\$ 0.05-1.00$ & $\mathrm{y}$ & 2001 & Boysen et al. 2002 \\
\hline WY & Injection & $\$ 0.40-1.50$ & $\mathrm{y}$ & 1998 & Boysen et al. 2002 \\
\hline WY & Injection & $\$ 0.10-0.95$ & $\mathrm{y}$ & 1998 & Boysen et al. 2002 \\
\hline AL & Injection & $\$ 0.35-0.50$ & $\mathrm{n}$ & 2006 & Puder and Veil 2006 \\
\hline AR & Injection & $\$ 0.40-0.75$ & $\mathrm{n}$ & 2006 & Puder and Veil 2006 \\
\hline LA & Injection & $\$ 0.50-10.00$ & $\mathrm{n}$ & 2006 & Puder and Veil 2006 \\
\hline MI & Injection & $\$ 0.50-1.75$ & $\mathrm{n}$ & 2006 & Puder and Veil 2006 \\
\hline MS & Injection & $\$ 0.37-0.60$ & $\mathrm{n}$ & 2006 & Puder and Veil 2006 \\
\hline ND & Injection & $\$ 0.35-0.75$ & $\mathrm{n}$ & 2006 & Puder and Veil 2006 \\
\hline NM & Injection & $\$ 0.40-0.88$ & $\mathrm{n}$ & 2006 & Puder and Veil 2006 \\
\hline OK & Injection & $\$ 0.30-0.65$ & $\mathrm{n}$ & 2006 & Puder and Veil 2006 \\
\hline TX & Injection & $\$ 0.40-4.00$ & $\mathrm{n}$ & 2006 & Puder and Veil 2006 \\
\hline WV & Injection & $\$ 1.00$ & $\mathrm{n}$ & 2006 & Puder and Veil 2006 \\
\hline WY & Injection & $\$ 2.00-3.00$ & $\mathrm{n}$ & 2006 & Puder and Veil 2006 \\
\hline $\mathrm{AL}$ & Evaporation & $\$ 2.10$ & ? & 1992 & Nakles et al. 1992 \\
\hline $\mathrm{CO}$ & Evaporation & $\$ 0.05$ & $\mathrm{y}$ & 1998 & Boysen et al. 2002 \\
\hline WY & Evaporation & $\$ 0.50-1.95$ & $\mathrm{y}$ & 1998 & Boysen et al. 2002 \\
\hline WY & Evaporation & $\$ 1.50-4.00$ & $\mathrm{y}$ & 1998 & Boysen et al. 2002 \\
\hline $\mathrm{CO}$ & Evaporation & $\$ 1.20-3.95$ & $\mathrm{n}$ & 2006 & Puder and Veil 2006 \\
\hline NM & Evaporation & $\$ 0.40-0.78$ & $\mathrm{n}$ & 2006 & Puder and Veil 2006 \\
\hline UT & Evaporation & $\$ 0.50-1.00$ & $\mathrm{n}$ & 2006 & Puder and Veil 2006 \\
\hline
\end{tabular}

a Costs have not been corrected for inflation, the year associated with the cost is given

b Informal verbal quote given to authors by treatment facility operator. 
TABLE 11 Costs for Treatment to Remove TDS

\begin{tabular}{|c|c|c|c|c|c|}
\hline State & Management Practice & Cost $/ \mathrm{bbl}^{\mathrm{a}}$ & $\begin{array}{c}\text { Transport } \\
\text { Cost } \\
\text { Included }\end{array}$ & Year & Source \\
\hline WY & Reverse Osmosis & $\$ 2.50-3.50$ & $\mathrm{n}$ & 2006 & Puder and Veil 2006 \\
\hline MT & Reverse Osmosis & $\$ 1.04-1.39$ & $\mathrm{n}$ & 2006 & EEA 2006 \\
\hline NM & Reverse Osmosis & $\$ 0.75-1.50$ & ? & 1992 & Nakles et al. 1992 \\
\hline AL & Reverse Osmosis & $\$ 0.45$ & ? & 1992 & Nakles et al. 1992 \\
\hline Any & Thermal Distillationb & $\$ 8.45$ & $\mathrm{n}$ & 2010 & Kohl 2010 \\
\hline $\mathrm{PA}$ & Thermal Distillation ${ }^{\mathrm{b}}$ & $\$ 6.70$ & $\mathrm{n}$ & 2010 & Quote $^{\mathrm{C}}$ \\
\hline Any & Capacitive Deionization & $\$ 1.00^{\mathrm{d}}$ & $\mathrm{n}$ & 2007 & Atlas and Wendell 2007 \\
\hline
\end{tabular}

a Cost for TDS of 10,000 mg/l; costs increase with higher concentrations.

b Includes all pre-treatment.

c Informal verbal quote given to authors by treatment facility operator.

d Cost for TDS of 10,000 mg/l; costs increase with higher concentrations.

TABLE 12 Cost for Transporting Water

\begin{tabular}{|c|c|c|c|c|}
\hline State & $\begin{array}{c}\text { Transportation } \\
\text { Mode }\end{array}$ & Cost & Year & Source \\
\hline MT & Pipeline & \$0.006-0.010/bbl-mile & 2006 & EEA 2006 \\
\hline $\mathrm{CO}$ & Truck & $\$ 0.40-0.65 / \mathrm{bbl}$ & 1998 & Boysen et al. 2002 \\
\hline NM & Truck & $\$ 0.70-3.20 / \mathrm{bbl}$ & 2001 & Boysen et al. 2002 \\
\hline NM & Truck & $\$ 1.00-3.00 / \mathrm{bbl}$ & 2006 & Puder and Veil 2006 \\
\hline Many & Truck & $\$ 55-100 / \mathrm{hr}$ & 2006 & Puder and Veil 2006 \\
\hline
\end{tabular}

Tables 10 and 11 indicate whether transportation costs are included in the reported costs of water management. These costs can make up a significant fraction of the total water management costs. Boysen et al. (2002) reported in many specific cases that transportation made up the majority of water management costs, including one specific region where producers reported that transportation made up 50 to $75 \%$ of the total cost of water management. The two main transportation options are pipelines and trucks. Pipelines tend to be more economical for shorter distances and where water production is stable and anticipated for an extended period of time. Trucking is a better option when water production is more intermittent or for longer transportation distances. Pipeline costs have been estimated at about $\$ 0.01 / \mathrm{bbl}$ per mile with per barrel costs declining slightly as pipeline length declines. Typical water trucks can haul from 100 to 150 bbl per load and are usually contracted out with prices ranging from $\$ 55$ to \$100/hr with an operator. Costs are highly dependent upon distance and the time it takes to load and unload the truck along with any applicable cleaning fees (Puder and Veil 2006). 
Using the values calculated in Chapter 3 for the volume of water that would need to be managed, we can get an idea of the extent that water management might add to the cost of carbon sequestration. At the low end of the cost spectrum of $\$ 0.10 / \mathrm{bbl}$ for discharge or injection in an adjacent formation, costs would range from $\$ 0.80$ to $\$ 0.95 /$ metric ton of $\mathrm{CO}_{2}$ sequestered. At $\$ 1.50 / \mathrm{bbl}$ which could include injection with transportation, evaporation, or treatment using RO or capacitive deionization for recycling of relatively low TDS waters, costs for sequestration would increase by $\$ 12$ to $\$ 14 /$ metric ton. At the high end, the costs of $\$ 7 / b b l$ for thermal treatment and long distance trucking for disposal of high TDS waters, the cost for sequestration would increase by $\$ 57$ to $\$ 67 /$ metric ton. Given that carbon sequestration is currently viewed as a pure cost to the energy industry, it seems unlikely that voluntary water extraction would be justified in areas where the costs of management are high. However, in areas with nearby formations, where injection can be performed inexpensively and with minimal transportation costs, or where TDS are low and RO systems can take advantage of pressurized wells to minimize costs, there may be opportunities to extract water at reasonable costs. 


\section{CONCLUSIONS}

Carbon sequestration is still in its infancy. As projects move beyond the pilot and demonstration stages, there may be situations in which water extraction from formations is an integral part of a large, multi-year injection program. As of the end of 2010, no CCS project has intentionally extracted water to create additional pore space. Water extraction will not automatically or always be a mandatory component of large CCS programs. However, if an operator proposes to extract water for project operational and control purposes, the operator must carefully consider how a substantial volume of saline ground water can be managed.

A number of water management strategies have been explored based upon the experience of the oil and gas industry. Quite a few of these options can be applied to managing extracted water. The actual options selected will reflect site-specific technical feasibility and practicality, regulatory acceptability, and cost. The water composition of any deep saline formation selected for a $\mathrm{CO}_{2}$ injection program will play a critical role in the options selected and the types of treatment required for that water.

In addition to selecting appropriate water management practices, other important issues to consider in water extraction include the following questions.

- When should water be extracted (before injection or throughout the injection)?

- How should water be extracted (continuously, intermittently, or different rates at different times)?

- Where should water be extracted (at or near the injection point, down gradient at one point, or down gradient at multiple points)?

- How many injection wells should be employed (one or multiple wells with orientation optimized to allow some measure of "plume steering")?

- How much water should be extracted (as much as possible, match the volume of injected $\mathrm{CO}_{2}$, or other)?

Much of the information needed to answer these questions can be derived by using experience, models, and data already developed for other industries such as the oil and gas and geothermal industries. 


\section{REFERENCES}

Atlas, R., and J. Wendell, 2007, "Purification of Produced Water Using Hybrid CDI-ED Technology," presented at the 14th International Petroleum Environmental Conference, Houston, TX, November 5-9. Available at http://ipec.utulsa.edu/Conf2007/Papers/Atlas_77a.pdf.

Bentham, M. and G. Kirby, 2005, " $\mathrm{CO}_{2}$ Storage in Saline Aquifers," Oil \& Gas Science and Technology, 60(3):559-567.

Boysen, D.B., J.E. Boysen, and J.A. Boysen, 2002, "Strategic Produced Water Management and Disposal Economics in the Rocky Mountain Region,” presented at the 2002 9th Annual International Petroleum Environmental Conference, Albuquerque, NM - October 22-25. Available at http://ipec.utulsa.edu/Conf2002/boysen_89.pdf.

Clark, C.E., C.B. Harto, J.L. Sullivan, and M.Q. Wang, 2011, "Water Use in the Development and Operation of Geothermal Power Plants," ANL/EVS/R-10/5, prepared for the U.S. Department of Energy, Energy Efficiency and Renewable Energy, Office of Geothermal Technologies, January.

Clark, C.E., and J.A. Veil, 2009, "Produced Water Volumes and Management Practices in the United States,” ANL/EVS/R-09/1, prepared for the U.S. Department of Energy, National Energy Technology Laboratory, September, 64 pp.

Duffield, W.A., and J.H. Sass, 2003, "Geothermal Energy — Clean Power From the Earth's Heat,” U.S. Geological Survey Circular 1249. Available at http://pubs.usgs.gov/circ/2004/ c1249/c1249.pdf.

EEA (Energy and Environmental Analysis, Inc.), 2006, "Economic Impacts of Proposed Montana CBM Water Management Regulations in the Powder River Basin," submitted to State of Montana Board of Environmental Review.

Grimaldi, M.C., W.J. Castrisana, F.C. Tolfo, F.P. Christino, L.M.L. Geraldo, G.C. Saliba, and D.E.B. Lopes, 2010, "Produced Water Reuse for Production of Chemicals," SPE 127174, presented at the SPE International Conference on Health, Safety, and Environment in Oil and Gas Exploration and Production, Rio de Janeiro, Brazil, April 12-14.

Johnson, L.A., and E.D. Walker, 2010, “Ormat: Low-Temperature Geothermal Power Generation,” (DOE-RMOTC-61022), March. Available at http://www.rmotc.doe.gov/PDFs/ Ormat_report.pdf. Accessed July 22, 2010.

Kobos, P.H., J.L. Krumhansl, T.A. Dewers, J.E. Heath, M.A. Cappelle, D.J. Borns, G.T. Klise, B.P. Dwyer, and A. McNemar, 2009, "Combining Power Plant Water Needs and Carbon Storage using Saline Formations: An Assessment Tool," presented at the Eighth Annual Conference on Carbon Sequestration and Storage, Pittsburgh, PA, May 4-7. 
Kohl, D.C., 2010, Presentation to the Senate Environmental Resources and Energy Committee, January 27. Available at http://www.senatormjwhite.com/environmental/2010/012710/kohl.pdf.

Lehr, L., A.D. Allen, and R. Lease, 1982, "Potential for By-Product Recovery in Geothermal Energy Operations," Energy and Economics Research Inc., Vienna, VA. Prepared for Geothermal and Hydropower Division, U.S. Department of Energy.

Nakles, D.V., I. Ortiz, and J.R. Frank, 1992, “An analysis of Management Strategies for Produced Waters from Natural Gas Production,” in Produced Water: Technological/ Environmental Issues and Solutions, edited by J.P. Ray and F.R. Engelhardt, Plenum Press: New York.

National Energy Technology Laboratory (NETL), 20010, “2010 Carbon Sequestration Atlas of the United States and Canada,” U.S. Department of Energy, Office of Fossil Energy, National Energy Technology Laboratory. Available at http://www.netl.doe.gov/technologies/carbon_seq/refshelf/atlasIII/2010atlasIII.pdf. Accessed February 11, 2011.

Puder, M.G., and J.A. Veil, 2006, "Offsite Commercial Disposal of Oil and Gas Exploration and Production Waste: Availability, Options, and Costs,” prepared by Argonne National Laboratory for the U.S. Department of Energy, Office of Fossil Energy and National Energy Technology Laboratory, August.

U.S. Department of Energy (USDOE), 2011, "Technologies for Extracting Valuable Metals and Compounds from Geothermal Brines,” Available at http://apps1.eere.energy.gov/geothermal/projects/projects.cfm/ProjectID=169. Accessed February 11, 2011.

U.S. Environmental Protection Agency (USEPA), 2010a, "Drinking Water Contaminants.” Available at http://www.epa.gov/safewater/ contaminants/index.html. Accessed July 15, 2010.

Veil, J.A., M.G. Puder, D. Elcock, and R.J. Redweik, Jr., 2004, “A White Paper Describing Produced Water from Production of Crude Oil, Natural Gas, and Coal Bed Methane,” prepared by Argonne National Laboratory for the U.S. Department of Energy, National Energy Technology Laboratory, January.

Wolery, T.J., R.D. Aines, Y. Hao, W. Bourcier, T. Wolfe, and C. Haussman, 2009, "Fresh Water Generation from Aquifer-Pressurized Carbon Storage: Annual Report FY09,” prepared by Lawrence Livermore National Laboratory for the U.S. Department of Energy, December. 


\section{APPENDIX A:}

Table of Deep Saline Formations That Have Geochemical Data Available 


\begin{tabular}{|c|c|c|c|c|c|c|c|}
\hline Name & Partnership & Depth (ft) & $\begin{array}{c}\text { Storage } \\
\text { Capacity (Gt) }\end{array}$ & Data Points & $\begin{array}{c}\mathrm{pH} \\
\text { Median }\end{array}$ & $\begin{array}{l}\text { TDS Median } \\
(\mathrm{mg} / \mathrm{L})\end{array}$ & $\begin{array}{c}\text { TDS Average } \\
(\mathrm{mg} / \mathrm{L})\end{array}$ \\
\hline Antelope Valley Basin & WESTCARB & & & 4 & 7.5 & 26,551 & 23,381 \\
\hline Appalachian Basin & MRCSP & $5,900-8,300$ & & 84 & 5.9 & 253,767 & 238,421 \\
\hline Arbuckle & SWP, SECARB & & & 3043 & 7 & 38,442 & 54,733 \\
\hline Astoria-Nehalem Basin & WESTCARB & 4,700 & 1-12 & 0 & & & \\
\hline Basal Conasauga Sandstones & MRCSP & & $0.4-1.7$ & 21 & 7.2 & 57,014 & 90,116 \\
\hline Bass Islands Group & Big Sky & & $1.6-6$ & 3 & 8.2 & 199,704 & 210,202 \\
\hline Big Horn Basin & Big Sky & & $11-146$ & 2113 & 7.7 & 5,004 & 9,015 \\
\hline Broom Creek Formation & PCOR & & 5 & 1 & 7.9 & 12,286 & \\
\hline Cape Fear & SECARB & & & 0 & & & \\
\hline Cedar Keys, Lawson Formations & SECARB & & 11-153 & 1 & 7.8 & 35,119 & \\
\hline Cedar Mesa & SWP & & & 0 & & & \\
\hline Central Valley & WESTCARB & 20-282 & & 0 & & & \\
\hline Cincinnati Arch & MRCSP & $3,200-3,500$ & & 9 & 6.9 & 58579 & 57,355 \\
\hline Colorado Plateau & WESTCARB & 5,000 & & 0 & & & \\
\hline Columbia Plateau & Big Sky & & & 0 & & & \\
\hline Cook Inlet Basin & WESTCARB & & & 37 & 6.3 & 228,191 & 219,464 \\
\hline Coos Basin & WESTCARB & 7,500 & & 0 & & & \\
\hline Cuyama Basin & WESTCARB & & 1-15 & 0 & & & \\
\hline Cypress Sandstone & MGCS & 3,000 & $0.4-1.7$ & 75 & 6.6 & 106,427 & 106,693 \\
\hline Dakota & SWP & & & 1535 & 8 & 8,113 & 13,950 \\
\hline Devonian & SWP & & & 895 & 6.9 & 63,973 & 92,249 \\
\hline Dockum & SWP & & & 1 & & 7,174 & \\
\hline Eel River Basin & WESTCARB & & 1 & 0 & & & \\
\hline Entrada & SWP & $9,000-12,000$ & & 48 & 7.3 & 12,830 & 24,935 \\
\hline Fountain & SWP & & & 2 & 7.7 & 5,204 & \\
\hline Frio & SECARB & & & 917 & 7.1 & 37,241 & 54,354 \\
\hline Glorieta & SWP & & & 231 & 7.4 & 79,344 & 97,864 \\
\hline Granite Springs Valley Basin & WESTCARB & & & 0 & & & \\
\hline Green River Basin & SWP, Big Sky & & & 2865 & 8 & 10,488 & 17,362 \\
\hline Gulf Coast Eocene & SECARB & & $160-2,200$ & & & & \\
\hline Gulf Coast Miocene & SECARB & & $400-5,500$ & & & & \\
\hline Gulf Coast Oligocene & SECARB & & $130-1,800$ & & & & \\
\hline Gulf Coast Olmos & SECARB & & 0.4-6 & & & & \\
\hline Gulf Coast Pliocene & SECARB & & $140-1,900$ & & & & \\
\hline Gulf Coast Tertiary Undivided & SECARB & & $17-240$ & & & & \\
\hline Gulf Coast - All & SECARB & & & 7453 & 7.1 & 56,694 & 71,120 \\
\hline
\end{tabular}




\begin{tabular}{|c|c|c|c|c|c|c|c|}
\hline Name & Partnership & Depth (ft) & $\begin{array}{c}\text { Storage } \\
\text { Capacity (Gt) }\end{array}$ & Data Points & $\begin{array}{c}\mathrm{pH} \\
\text { Median }\end{array}$ & $\begin{array}{l}\text { TDS Median } \\
(\mathrm{mg} / \mathrm{L})\end{array}$ & $\begin{array}{c}\text { TDS Average } \\
(\mathrm{mg} / \mathrm{L})\end{array}$ \\
\hline Hermosa & SWP & & & 283 & 7 & 110,022 & 126,527 \\
\hline Illinois Basin & MGSC & $7,000-8,600$ & & 912 & 7 & 116,577 & 104,431 \\
\hline Ione Valley Basin & WESTCARB & & & 0 & & & \\
\hline Jackson & SECARB & & & 16 & 7.4 & 25,892 & 80,470 \\
\hline Jasper & SECARB & & & 0 & & & \\
\hline Knox Group & MRCSP & & 30 & 6 & 7.6 & 16,716 & 25,796 \\
\hline La Honda Basin & WESTCARB & & 1 & 0 & & & \\
\hline Lakota & PCOR, Big Sky & $4,100-6,700$ & & 138 & 8.1 & 5,484 & 8,617 \\
\hline Leadville & SWP & & & 10 & 7.1 & 61,800 & 75,846 \\
\hline Livermore Basin & WESTCARB & & $<1$ & 0 & & & \\
\hline Lockport Group & MRCSP & & $4.5-18$ & 6 & 6.6 & 221,090 & 232,540 \\
\hline Los Angeles Basin & WESTCARB & & 5-35 & 264 & 7.4 & 30,354 & 28,491 \\
\hline Lyons & SWP & & & 161 & 7.6 & 27,742 & 35,319 \\
\hline Madison Formation & PCOR & $4,000-16,000$ & 37 & 2280 & 6.9 & 51,142 & 120,112 \\
\hline Maha Formation & PCOR & & 3 & 0 & & & \\
\hline Medina/Tuscarora Sandstone & MRCSP & & $7.9-32$ & 12 & 6.3 & 251,276 & 236,785 \\
\hline Mesaverde & SWP & $4,000-11,000$ & & 1517 & 8.0 & 9,246 & 13,754 \\
\hline Michigan Basin & MRCSP & $3,200-3,500$ & & 269 & 5.8 & 303,516 & 279,597 \\
\hline Montana Thrust Belt & Big Sky & & $2.5-34$ & 16 & 7.3 & 3,031 & 2,938 \\
\hline Morrison & SWP & $3,600-12,000$ & & 303 & 8.0 & 10,984 & 14,792 \\
\hline Mount Simon Sandstone & $\begin{array}{l}\text { MGSC, MRCSP, } \\
\text { SECARB }\end{array}$ & 2,000 to 14,000 & $11-151$ & 0 & & & \\
\hline Newcastle Formation & PCOR & 6,700 & 1 & 122 & 8.0 & 10,841 & 11,710 \\
\hline North-Central Montana & Big Sky & & $68-933$ & 689 & 7.9 & 5,236 & 8,856 \\
\hline Ochoco Basin & WESTCARB & & $1-12$ & 0 & & & \\
\hline Offshore Atlantic Unit 120 & SECARB & & $36-490$ & 0 & & & \\
\hline Offshore Atlantic Unit 90 & SECARB & & 3-43 & 0 & & & \\
\hline Orinda Basin & WESTCARB & & 1 & 0 & & & \\
\hline Oriskany Sandstone & MRCSP & & $1.9-7.8$ & 207 & 4.6 & 253,770 & 219,423 \\
\hline Paradox & SWP & & & 467 & 7.1 & 80,989 & 103,021 \\
\hline Potomac Group & SECARB & & $2-25$ & 0 & & & \\
\hline Potsdam Sandstone & MRCSP & & $0.2-1.7$ & 0 & & & \\
\hline Pottsville Formation & SECARB & & $1.1-15$ & 1 & & 361321 & \\
\hline Powder River Basin & PCOR, Big Sky & & 14-196 & 2912 & 8 & 7,812 & 18,248 \\
\hline Puget Trough Basin & WESTCARB & & $35-475$ & 0 & & & \\
\hline Redwall & SWP & & & 11 & 7 & 9,257 & 51,782 \\
\hline
\end{tabular}




\begin{tabular}{|c|c|c|c|c|c|c|c|}
\hline Name & Partnership & Depth (ft) & $\begin{array}{c}\text { Storage } \\
\text { Capacity (Gt) }\end{array}$ & Data Points & $\begin{array}{c}\mathrm{pH} \\
\text { Median }\end{array}$ & $\begin{array}{l}\text { TDS Median } \\
(\mathrm{mg} / \mathrm{L})\end{array}$ & $\begin{array}{c}\text { TDS Average } \\
(\mathrm{mg} / \mathrm{L})\end{array}$ \\
\hline Reese River Valley Basin & WESTCARB & & & 0 & & & \\
\hline Rome Trough Sandstones & MRCSP & & $0.1-0.8$ & 0 & & & \\
\hline Rose Run Sandstone & MRCSP & & $5.7-23$ & 1 & 6.1 & 201467 & \\
\hline Sacramento Basin & WESTCARB & & $50-250$ & 12 & 6.4 & 16,665 & 16,633 \\
\hline Salinas Basin & WESTCARB & & $1-15$ & 1 & & 31094 & \\
\hline Salton Trough & WESTCARB & & $5-40$ & 0 & & & \\
\hline San Andres & SWP & & & 1310 & 7.1 & 76,286 & 105,958 \\
\hline San Joaquin Basin & WESTCARB & & $50-250$ & 195 & 7.4 & 21,982 & 22,424 \\
\hline San Juan Basin & SWP & & & 283 & 7.4 & 19,130 & 36,585 \\
\hline Snake River Plain & Big Sky & & & 3 & 7.8 & 11,930 & \\
\hline South Carolina - Georgia Basin & SECARB & & $13-60$ & 0 & & & \\
\hline Southwest Montana & Big Sky & & 1.9-26 & 57 & 7.9 & 3,118 & 3,855 \\
\hline Southwestern Wyoming & Big Sky & & $47-640$ & 2425 & 8 & 9,177 & 15,492 \\
\hline St. Peter Sandstone & MRCSP & & $8.8-35$ & 26 & 6.7 & 86,737 & 87,715 \\
\hline Sylvania Sandstone & MRCSP & & $1.5-3.5$ & 0 & & & \\
\hline Tapeats & SWP & & & 0 & & & \\
\hline Tofino-Fuca Basin & WESTCARB & 5,300 & $0.5-4$ & 0 & & & \\
\hline Tuscaloosa Group & SECARB & & $5-75$ & 935 & 6.1 & 147,556 & 137,298 \\
\hline Tyee-Umpqua Basin & WESTCARB & 5,300 & & 0 & & & \\
\hline Ventura Basin & WESTCARB & & $5-35$ & 16 & 7.3 & 30,220 & 29,598 \\
\hline Vicksburg & SECARB & & & 156 & 6.9 & 25,074 & 32,627 \\
\hline Viking Formation & PCOR & & 60 & 0 & & & \\
\hline Wasatch & SWP & $2,600-3,400$ & & 600 & 7.9 & 10,711 & 16,156 \\
\hline Waste Gate Formation & MRCSP & & $0.4-1.8$ & 0 & & & \\
\hline Weber & SWP & $9,000-14,000$ & & 210 & 7.4 & 35,700 & 57,762 \\
\hline Western Olympic Basin & WESTCARB & 3,500 & $0.5-4$ & 0 & & & \\
\hline Whatcom Basin & WESTCARB & & $0.2-3$ & 0 & & & \\
\hline Willamette Trough & WESTCARB & & & 0 & & & \\
\hline Willapa Hills Basin & WESTCARB & 7,500 & 1-12 & 0 & & & \\
\hline Williston Basin & PCOR, Big Sky & & $58-804$ & 3027 & 6.7 & 138,400 & 159,589 \\
\hline Wind River Basin & Big Sky & & $14-187$ & 1520 & 8 & 5,603 & 10,488 \\
\hline $\begin{array}{l}\text { Woodbine Formation and } \\
\text { Paluxy Sandstone }\end{array}$ & SECARB & & 5-70 & 440 & 7.4 & 56,773 & 59,156 \\
\hline Woodward Trench & SWP & & & 0 & & & \\
\hline Wyoming Thrust Belt & Big Sky & & $5.3-74$ & 191 & 7.3 & 18,872 & 34,261 \\
\hline
\end{tabular}





\section{Argonne}

\section{Environmental Science Division}

Argonne National Laboratory

9700 South Cass Avenue, Bldg. 240

Argonne, IL 60439-4847

www.anl.gov 